FACTORS INELUENCING KAMIK PRODUCTION IN ARCTIC BAY, Northwest Territories

by

Jill E. OARES

\author{
A thesis \\ presented to the University of Manitoba \\ in partial fulfillment of the \\ requirements for the degree of \\ Master of Science \\ in \\ Department of clothing and Textiles.
}

April, 1985 


\section{FACTORS INFLUENCING KAMIK PRODUCTION IN ARCTIC BAY, NORTHWEST TERRITORIES}

BY

JILLIAN E. OAKES

A thesis submitted to the Faculty of Graduate Studies of the University of Manitoba in partial fulfillment of the requirements of the degree of

MASTER OF SCIENCE

(c) 1985

Permission has been granted to the LIBRARY OF THE UNIVERSITY OF MANITOBA to lend or sell copies of this thesis, to the NATIONAL LIBRARY OF CANADA to microfilm this thesis and to lend or sell copies of the film, and UNIVERSITY MICROFILMS to publish an abstract of this thesis.

The author reserves other publication rights, and neither the thesis nor extensive extracts from it may be printed or otherwise reproduced without the author's written permission. 


\section{ABSTRACT}

The purpose of this study was to describe skin boot production in Arctic Bay and to analyze the factors influencing kamik production. This description may be valuable to northern educators, applied anthropologists, folklorists, ethnologists, and curators.

Sealskin preparation and boot construction techniques were collected through participantobservation. Experienced seamstresses volunteered to act as key informants. They provided information on pattern development, pattern layout, cutting skins, design trends, boot styles, thread preparation, assembly of pieces, fitting, and maintenance- of kamiks.

Influencing factors were divided into social, physical, and economic categories. Family size, lifestyle, health, knowledge, age, sex, time, and abilities of the seamstress; the availability, price, and condition of seal pelts; and the season, terrain, social occasion, and end use of skin boots influenced their production. 
ACRNOWLEDGEMENTS

In 1978, Dr. Riewe's discussion of the mysteries surrounding kamik construction captured my attention and inspired this research project. His advice and support has continued throughout my research and is gratefully acknowledged.

I wish to thank Lazaroosie Akpaleapik, Elizapee Alooloo, Morty Alooloo, Natsiq Alainga, Qapiq Attagutsiak, Bo Brown, Koonoo Campbell, Oorebecca Issuganqituq, Attagootak Ipilee, Qumanagpik Muckpa, and Martha Willie of Arctic Bay. Their grateful assistance and cooperation made this project possible. I am thankful to my supervisor, Professor Tyrchniewicz, for her guidance and faith in my ability to complete this research. Professor Gonzales, Dr. Koolage, Betty Issenman, Cathy Welch, Lorraine Brandson, Jack Cram, Alan Cooke, John MacDonald, Judy Hall, Jim Forester, and Louise Dallaire are thanked for their assistance. Stephen Jackson is acknowledged for the diagrams in this thesis and Mike Bryan is thanked for reproducing my slides.

Financial assistance received from the Northern Studies Committee, University of Manitoba, is gratefully acknowledged. 
TABLE OF CONTENTS

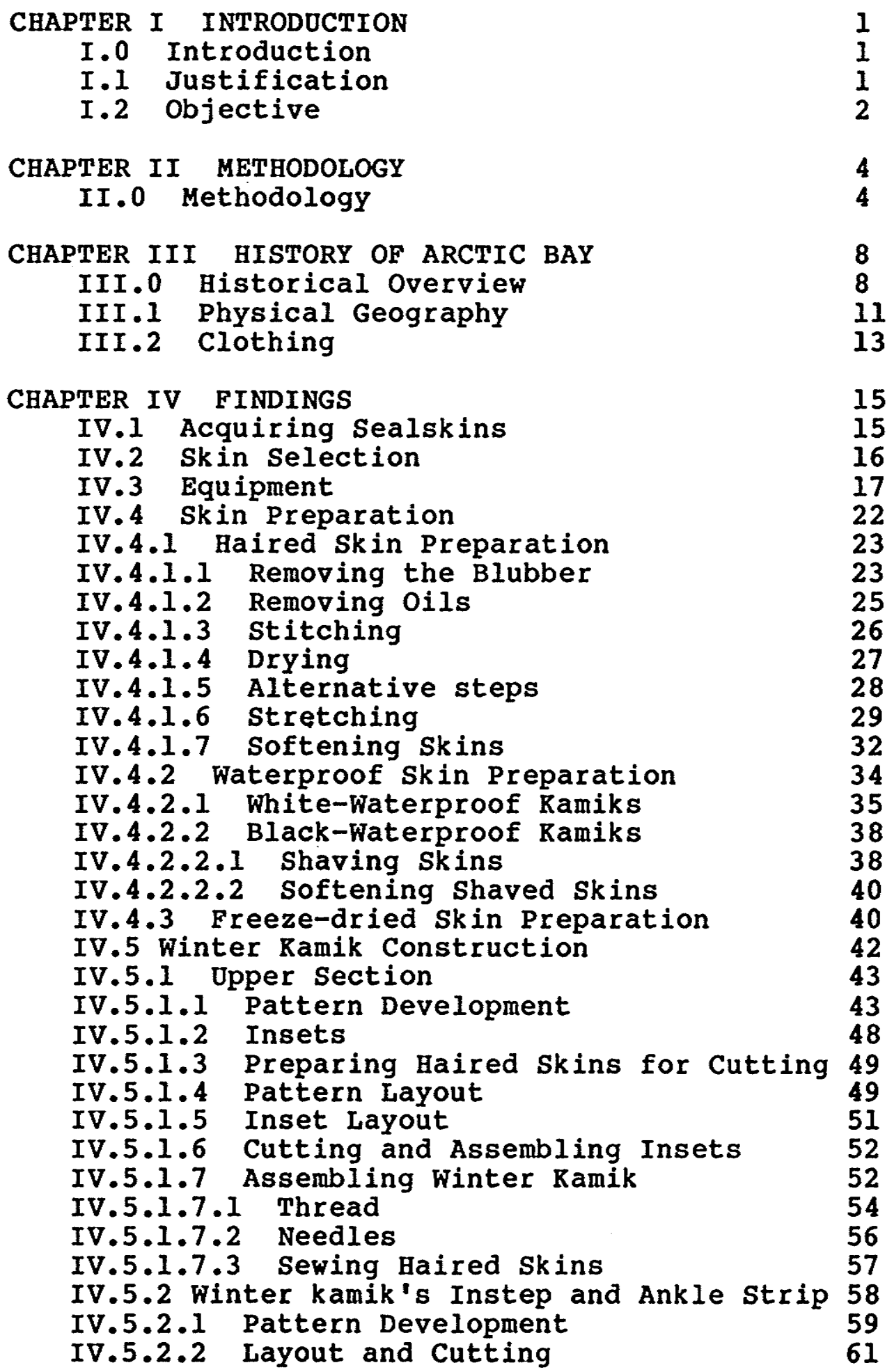


TABLE OF CONTENTS (CONTINUED)

IV.5.2.3 Assembly $\quad 62$

IV.5.3 Soles 63

IV.5.3.1 Pattern Development 64

IV.5.3.2 Layout 65

IV.5.3.3 Softening Soles 65

IV.5.3.4 Assembly 67

IV. 6 Spring Ramik Construction 73

IV.6.I Upper Section 75

IV.6.1.1 Design Development 76

IV.6.1.2 Spring Kamik Insets 77

IV.6.1.3 Layout and cutting 78

IV.6.1.4 Sewing 78

IV.6.2 Spring Kamik Instep $\quad 80$

IV.6.3 Soles 81

IV.7 Care and Maintenance of Kamiks 81

CHAPTER V SUMMARY AND CONCLUSIONS 86

V.0 Summary $\quad 86$

V.1 Conclusions $\quad 95$

V.2 Future Research 97

$\begin{array}{ll}\text { LITERATURE CITED } & 98\end{array}$

$\begin{array}{ll}\text { PRIMARY RESOURCE PERSONNEE } & 101\end{array}$ 


\section{LIST OF FIGURES}

Figure

Page

1 Map of Arctic Bay.

2. Ulus.

3. Scrapers.

4. Scraping platform.

5. Safe scraping position

6. Woman scraping a skin.

7. Drying skins.

8. Stretching skins.

9. Lashing skins to a frame.

10. Softening skins.

1I. Removing the epidermis.

12. Shaving a sealskin.

13. A hand span.

14. Upper section pattern.

15. Kamik silhouettes.

16. Pattern for upper edge of upper section. 47

17. Designs on male and female kamiks. 48

18. Layout for upper section of a man's kamik. 50

19. Layout for upper section of a woman's kamik 51

20. Ramik casings.

21. Narwhal tendons are dried and used for thread.

22. The instep pattern.

23. The cupped hand position. 


\section{LIST OF FIGURES (CONTINUED)}

Figure

Page

24. Three different instep seams.

25. The instep pattern layout.

26. The sole pattern.

27. Matching the sole to the upper section. 69

28. The first step of the waterproof stitch. 70

29. Turning a skin boot inside out. 71

30. A water-tight overcast stitch. 72

31. Water-proof kamiks made with shaved skins. 74

32. Ramiks made from skins with the hair and epidermis removed.

33. The second step of the water-proof stitch. 79

34. Water-proof kamik instep styles. 81

35. Ramik stretching post. 82 


\section{ILLUSTRATION CREDITS}

\section{figures:}

Stephen Jackson illustrated the following

Figure

1. Map of Arctic Bay. Title

2. Olus.

3. Scrapers.

4. Scraping platform.

6. Woman scraping a skin

13. A hand span.

14. Upper section pattern.

15. Kamik silhouettes.

16. Pattern for upper edge of upper section.

18. Layout for upper section of a man's kamik.

19. Layout for upper section of a woman's kamik.

20. Ramik casings.

22. The instep pattern.

23. The cupped hand position.

24. Three different instep seams.

25. The instep pattern layout.

26. The sole pattern.

27. Matching the sole to the upper section.

28. The first step of the waterproof stitch.

29. Turning a skin boot inside out.

30. A watertight overcast stitch.

33. The second step of the waterproof stitch.

34. Waterproof kamik instep styles. 


\section{Chapter I INTRODOCTION}

\section{0 INTRODUCTION}

Social changes modify fashion-oriented

behavior (Sproles 1979). Changing social and physical environments stimulate new patterns of social behavior and new activities resulting in new lifestyles. As these changes occur, new fashions can be introduced and accepted (Flugel 1950, Sproles 1979).

Inuit (historic inhabitants of the Eastern Arctic - "Eskimos") have experienced very few social changes over the centuries. This stability is reflected in the lack of change in traditional skin clothing. More recently, Inuit are living in a period of rapid social change. The effect of rapidly changing lifestyles on clothing needs may be described at this time.

\section{I.1 JUSTIFICATION}

For over 5,000 years Inuit have inhabited one of the harshest environments in the world, the Canadian Arctic (Herbert 1976). The long term survival of the Inuit depends upon their ability to adapt to changing social and physical environments. 
Social and physical changes, such as new women's roles and homesites, have placed new demands on clothing. Women use new techniques, equipment and materials to create kamiks which meet new footwear needs.

Traditional skin sewing techniques urgently need to be recorded before they are forgotten. Inuit footwear research includes a classification of Native North American footwear (Conn 1955), a description of circumpolar footwear (Hatt 1916), skin preparation techniques (Manning 1944) and Stefansson's (1945) documentation of Inuit clothing. Researchers in related areas have documented non-native arctic explorer's footwear (Schweger 1983) and have identified clothing styles in Igloolik (Pharand 1975, Driscoll 1981).

\section{I.2 OBJECTIVE}

The purpose of this research is to describe traditional and contemporary kamik (skin boot) production techniques. The scope of this thesis includes skin selection, skin preparation and kamik construction methods. Social, physical and economic 
factors influencing kamik production are discussed. This information will hopefully be useful to Inuit curriculum planning committees, ethnologists, applied anthropologists, curators, northern home economist educators, Inuit cultural centers and the Department of Indian and Northern Affairs.

In the following chapter, methods used to collect information are outlined. In chapter three a historical overview of the Arctic Bay region is presented. Chapter four describes the kamik production process, discusses relevant literature and points out factors relating to skin production. In chapter five the factors influencing skin boot production are discussed and conclusions are drawn. 


\section{CHAPTER II METHODOLOGY}

\section{0 METHODOLOGY}

Field research was selected as the most appropriate approach to solving the thesis problem. First hand experience at all stages of kamik production was necessary in order to understand factors which influence each step. Libraries, museums and archives provided additional background information. Formal questionnaires, laboratory studies and other data collecting techniques would not provide the detailed information and experience necessary to complete this research. Seamstresses from Arctic Bay were selected for this study because they were relatively isolated from southern influences. The following tools were used to collect information:

1. Museums, archives and literature were searched for historical information on skin preparation and construction techniques as well as political, ecological, social, economic, technical and physical issues concerning northern Baffin Island 
residents.

2. Interviews with Arctic Bay residents, assisted by an interpreter, were used to document traditional skin preparation and construction methods. The reasons for sewing or not sewing and wearing or not wearing kamiks were also discussed.

3. Participant-observation was used to provide an in-depth understanding of the processes and influencing factors in kamik construction.

The following resources were used:

a) Libraries

Dafoe Library, University of Manitoba, including extensive use of the University of Manitoba Inter-Library Loan Services..

Department of Anthropology Library, University of British Columbia, Vancouver.

Hudson Bay House Library and Photo collection, Winnipeg, Manitoba.

Northern Studies Library, McGill University, Montreal.

Science Library, University of Manitoba. Private northern libraries of Dr.'s W.O. Pruitt 
and R.R. Riewe, zoology Department, University of Manitoba.

b) Museums

Anthropology Museum, University of British

Columbia, Vancouver.

Churchill Eskimo Museum, Manitoba.

Manitoba Museum of Man and Nature, Winnipeg.

Museum of Man, Ottawa.

McCord Museum, Montreal.

c) Archives

Hudson Bay Archives, Winnipeg.

Provincial Archives, Winnipeg.

Public Archives of Canada, Ottawa.

d) Interviews

Seamstresses with a combination of qualities were selected to be interviewed. The women chosen were talented kamik seamstresses. They were willing. to volunteer their time and shared the researcher's concern for accuracy. Through participant-observation the researcher was able to determine whether statements and procedures were realistic or idealistic representations of kamik production. An unstructured interview technique was used to collect information on 
historical designs, construction methods and uses of kamiks. People that did not sew were also interviewed to collect information on factors influencing kamik production. Interviews were held at unscheduled times, in women's homes, work tents, hunting camps and on hikes across the tundra.

Interpreters would not interview the three eldest women. Informants said this was because questioning elders was disrespectful. As I began to learn more skills, elders generously volunteered their knowledge of kamik construction to me through interpreters.

e) Participation

Much of the data was collected by actively participating in the seal hunt, skin preparation and kamik construction processes. Previous Inuit skin preparation researchers have not used extensive participatory methodology. Several women acted as key informants, others gave valuable advise, criticism and encouragement as each step progressed. Field notes, photographs, sketches and samples were made of each stage.

Informants were renumerated with photographs and key informants were sent small gifts. A copy of the final paper, written in Inuktitut was promised to the Arctic Bay Museum as renumeration to the women who made this research possible. 


\section{Chapter III BISTORY OF ARCTIC BAY}

\section{III.0 HISTORICAL OVERVIEW}

Paleo-Eskimos were the first people to occupy the Eastern Arctic. Archaeologists have divided this group into two sub-groups: Early Paleo-Eskimo and Dorset Eskimo. Early Paleo-Eskimo existed when temperatures in the Eastern Arctic were higher than they are today. These people spread rapidly across the Canadian Arctic by 3000 B.C. and persisted until about 800 B.C. During this era animals and driftwood were plentiful. Most families depended on marine mammals, caribou and musk-ox. No major changes took place in the Early Paleo-Eskimo's settlement pattern for 3000 years (Bandi 1969, Bruemmer 1971, Fitzhugh. 1977, Herbert 1976, McGhee 1976, Taylor 1964).

The Dorset culture began with an increased utilization of marine foods and the development of winter ice hunting technology. Dorset culture lasted from 800 B.C. to A.D.1300. Technological changes in the Dorset culture led to the origins of Neo-Eskimo culture between 900 and 1300 A.D. Large skin boats, 
advanced harpoon gear and dogs helped produce a higher yield from the environment which characterized the Neo-Eskimo culture. The Thule culture emerged from the Neo-Eskimo culture. The Thule culture expanded rapidly, taking over neighboring hunting territories. This culture lasted until about 1750 A.D. and evolved into the Canadian Inuit culture. From 1650 to 1840 a "Little Ice Age" covered the High Arctic Islands, forcing Thule people to move to the southern coasts of Victoria Island, Boothia Penninsula and Baffin Island. Extensive ice cover, shorter seasons of open water, decreasing depths of sea passages and foreign whalers in northern waters were the known factors which influenced the Thule cultural transition to the Canadian Inuit (Taylor 1976).

Inuit on Baffin Island encountered foreigners for the first time when they met Frobisher in 1576 . During the next two and a half centuries, interaction between explorers and Inuit was rare. Explorers usually stayed on their ships and Inuit usually hunted inland when the water was open. During the $1800^{\prime} \mathrm{s}$, Europeans' searches for a northwest passage, Franklin's missing men, the North Pole, whales, and 
furs increased the amount of interaction between explorers and Inuit. Guns, ammunition and clothing were introduced to the Inuit's material culture. The Inuit produced furs, notably Arctic Fox, and also trinkets and momentos to trade for supplies. Non-natives did not generally attempt to emulate the the Inuit lifestyle. Boas, Hall, Schwatka, and Stefansson did adopt Inuit lifestyles, enabling them to document Inuit culture (Brody 1976, Ross 1976).

By the turn of the twentieth century, traders, missionaries, police, and scientists were introduced to northern Baffin Island. Inuit in the Arctic Bay area generally lived at outposts surrounding Admiralty Inlet, Lancaster sound and Adams Sound. A Hudson Bay post opened on the north shore of Arctic Bay in 1926. This post closed after one year and re-opened in 1936 (Brody 1976). In the late $1940^{\prime} \mathrm{s}$ child support payments were issued to northern residents. The following decade introduced pension plans and unemployment insurance programs to Inuit in the Arctic Bay area. By the 1950's medical staff, teachers and low rental housing were supplied by the federal government. During the early 1960's the Canadian government encouraged Inuit to settle into communities such as Arctic Bay rather than unserviced outposts. The Nanisivick mine opened in the late 
1960's, Pan Arctic oil explorations began in 1971 and government administrators, public works officers and telecommunication operators have since become a part of Arctic Bay's social environment. New job opportunities have created lifestyles which are heavily dependant on a wage economy. Today, Arctic Bay has a nursing station, a Hudson Bay Company store, two corner stores, a Bunters and Trappers Association, a Post Office, a Taxi-van service, a gravel air strip, a telecommunication network, an Anglican Church, an elementary school (to grade six) and a Royal Canadian Mounted Police detachment. A 17 kilometer long, narrow, winding gravel road leads to the Nanisivick airport and mine. Weather permitting, twice weekly flights arrive from Frobisher Bay bringing mail and supplies. Bulk supplies are delivered once a year by ship.

III.1 PHYSICAL GEOGRAPHY

Arctic Bay is located on the west coast of Borden Penninsula, northern Baffin Island. Approximately 450 people live at the base of a 2000 foot high mountain on the north shore of Arctic Bay. Looking across the bay is Adams sound which joins into Admiralty Inlet.(fig. 1) 


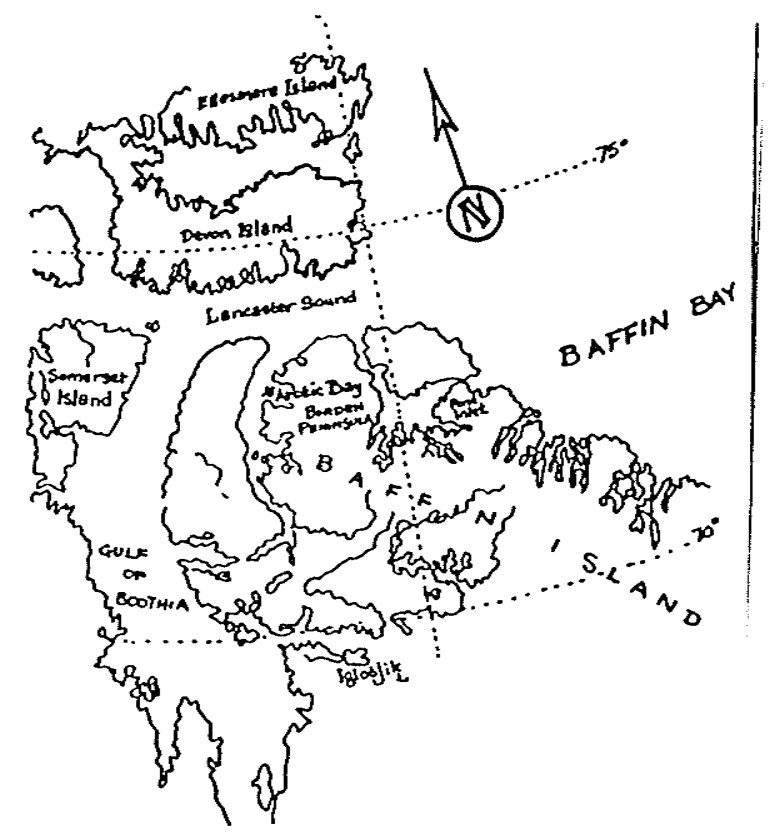

Figure 1. Map_of_Arctic_Bay. Arctic Bay is located on the northern tip of Baffin Island.

Average temperatures are $-29.7 \mathrm{C}$ in January and $5.6 \mathrm{C}$ in July. The salt water ice begins to clear in Adams Sound by July 16 and is usually completely clear by August 1. Sea ice normally re-forms by October 15. Snow can be expected at any time of the year. (Environment Canada 1982).

Environment Canada (1982) classifies Arctic Bay as a special interest area because of its geography and wildlife. This region contains small ice caps, turbulent streams, mature rivers, waterfalls, fiords and is a "polar desert". Caribou (Rangifer tarandus), ringed seal (Rhoca hispida), 
bearded seal (Erignathus barbatus), narwhal (Monodon monoceres), arctic fox (Alopex lagopus), polar bear (Ursus maritimus), arctic char (Salvelinus alpinus), sandpipers (Erolia spe), and arctic hare (Lepus arcticus), are found in the Arctic Bay region. Weather and the formation of ice affect the availability of these natural resources.

\section{III.2 CLOTHING}

Weather, seasons, ice conditions, and available resources partiy influence the type of clothing worn in Arctic Bay. The mean clo requirements for Arctic Bay are 4.50 for winter, 3.50 for spring and 3.00 for fall. A clo is a clothing unit which describes thermal resistance to heat flow along a temperature gradient. One clo is the insulation value of a standard business suit worn with undergarments normally used indoors (Auliciems et al 1973).

Traditionally, skin clothing was used to protect oneself from low temperatures and the year round chance of snow. Summer clothing was made from seal skins and winter clothing was made from caribou skins.

Today, southern-style clothing is worn in 
conjunction with skin clothing. In winter, hunters wear caribou skin parkas, pants and kamiks, women wear caribou amautiks (parkas) and kamiks and children wear caribou skin play suits and kamiks. Mass produced clothing is purchased from the Hudson Bay store, the High Arctic Trading Post, and the Simpson Sears catalogue. In summer, almost everyone wears southern-style clothing. Blue jeans, shirts, jackets, running shoes, and rubber boots are common apparel items. Ramiks are worn by older community members and by young children. Women carrying young children wear hand made, fabric amautiks. A few men wear seal skin parkas and pants when hunting during summer. 
Chapter IV. FINDINGS

Research findings are discussed in seven sections: acquiring sealskins, skin selection, equipment used, preparation of haired and dehaired skins, construction of winter and spring kamiks, and kamik maintenance.

\section{IV.I ACQUIRING SEALSKINS}

Today, men kill almost all seals used for skins. Hunting techniques have been documented extensively (Riewe \& Amsden 1979, Wenzel 1975). Hunters skin seals within half an hour of killing them or the sun will taint their fur. Turner (1894) and Graburn (1969) claimed that women usually skinned the seals. This may reflect regional differences in male-female roles as these authors travelled mainly in northern Quebec. Women in Arctic Bay rarely skinned seals. Seals are skinned by cutting a longitudinal slit through the underbelly skin and blubber, then the skin is sliced away from the blubber, leaving a thin layer of blubber on the skin and a thick layer on the carcass. The flippers are disarticulated at the first joint. Skinning continues up to and including the 
head and the animal is flipped onto its side to skin the back. An experienced hunter takes about five minutes to complete this process. Skins are tossed into a salty shoreline puddle and left for one to seven days at the hunting camps.

Skins are given to the hunter's sealskin sharing partner who is either his wife or a woman who will make good use of the skins (Minnie Freeman 1984 personal communications). This enables seamstresses not living with a hunter to acquire skins.

\section{IV.2 SRIN SELECTION}

Skins from mature seals, which are thicker and stiffer, are worn by hunters in winter. Winter kamiks designed for non-hunters are made from younger seals. Seals just under a year old are pliable and the silver hair is not discolored. Silver tinged and dark haired skins are prepared for use as contrasts in design insets. Children's kamiks are made from younger seal skins. The shorter hair and smaller pattern of color is better proportioned to a smaller kamik. Skins from seals under two weeks old are used for 
stockings and inner slippers. These skins have a dense, insulative, white coat of hair which is too fragile to make into kamiks.

Manning (1944) states that a good quality haired sealskin is one that is not molting. Adult seals shed their hair in May or June. These skins are not used as haired skins because the hair pulls out easily. Seals do not molt simultaneously, good quality haired skins can be found at any time of the year. Seals three to six months old are used for their thick, bushy, silver-tipped hair. Seals one year or older are used for their strong skins and dark hair. De-haired skins are rarely made from molting skins as the skin itself is discolored and scarred. Skins from seals killed in the fall are not scarred or bruised and are thicker than summer sealskins. These skins are ideal for de-haired skins. Manning (1944) observed that in Igloolik winter skins were not preferred except when freeze-dried skins were required.

IV.3 EQUIPMENT

Equipment needed for skin preparation includes a knife, a knife sharpener, a flat scraper, a curved scraper and a scraping platform. 
A moon-shaped knife, an $u l u$, is used in skin preparation and kamik construction. The size of the ulu varies with individual preferences and end uses. Using an ulu that is too big for the job is awkward, each woman has a variety of sizes. For small jobs, such as cutting thread, two or three inch blades are used. Seal skins are scraped and shaved with four to five inch blades. A triangular blade was developed to cut out letters with tight corners such as the crotch in " $\mathrm{Y}^{n}$ or " $\mathrm{W}$ ". Each leg of the triangular blade is approximately two inches Iong. (fig. 2)

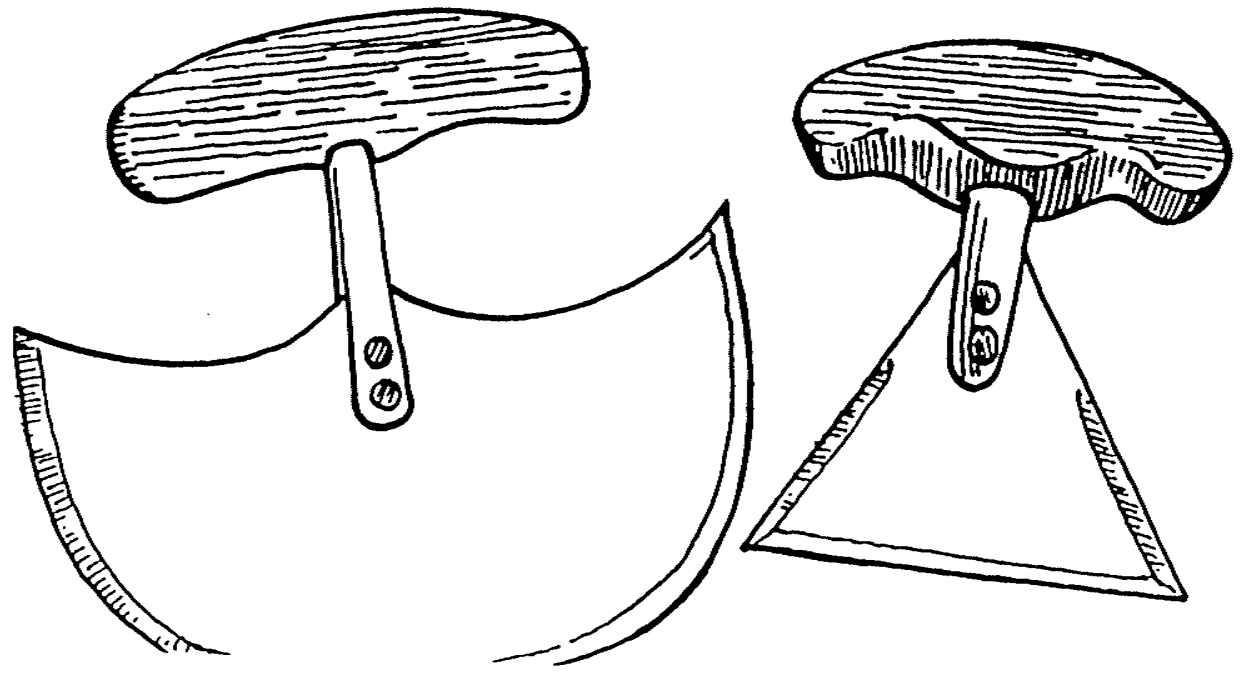

Figure 2. Uluss. An ulu is moon-shaped for most purposes. Small, triangular ulus have been created for cutting sealskin insets with tight corners. 
Knife blades are cut from a cross cut saw blade or a sheet of stainless steel. Stainless steel is preferred as it keeps a sharp edge longer than other metals and does not rust.

Handles are cut from a piece of plastic bread board, an old gun stock or scrap lumber and shaped so that the user's hand molds around it. A slit is cut up the center of the shaft which is rivetted to the blade. One plane of the blade is bevelled, a good quality ulu has an even bevel around the blade. The triangular style is bevelled half way up each side and along the bottom edge. The bevelled edge is sharpened with a sharpening steel purchased from the Hunters and Trappers Association in Arctic Bay. Manning (1944) states that traditionally, blades were made from stone and bone.

When women in Arctic Bay are preparing seal skins they use two types of scrapers: the curved and straight scrapers.(fig. 3) Both types have a blade made from a piece of metal about one-eighth of an inch thick. two and one-half inches wide and three inches long. Aluminum is not used as it blackens sealskins. 


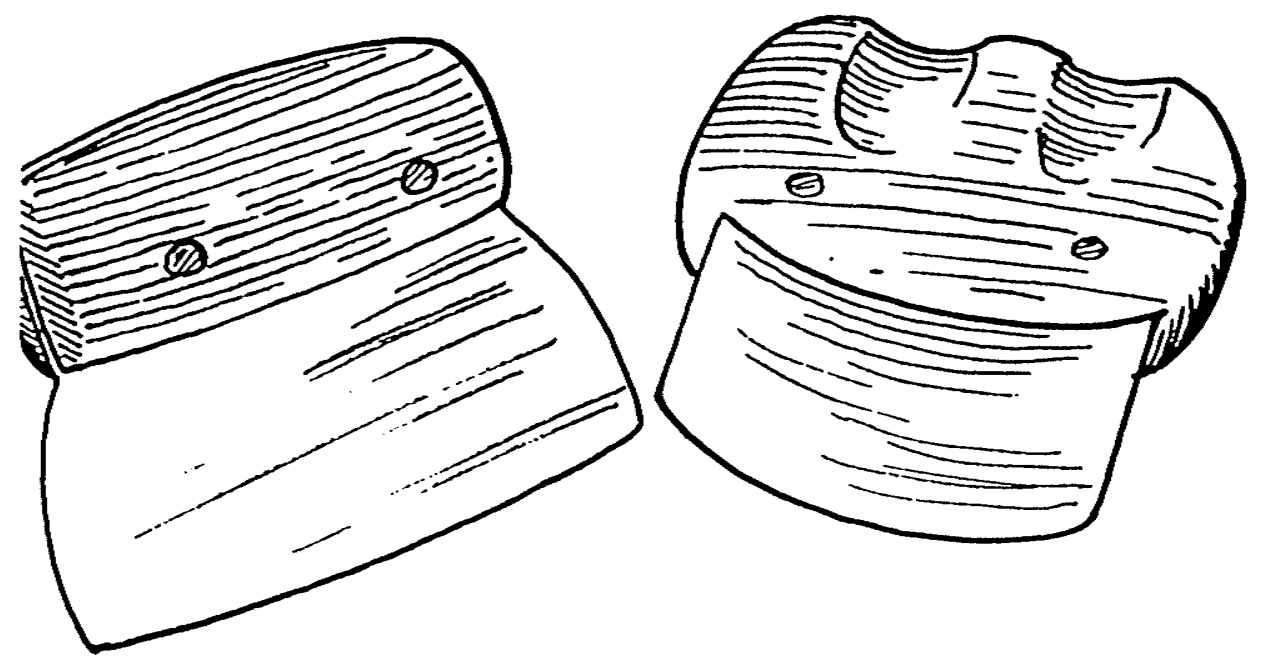

Figure 3. Scrapers. Straight and curved scrapers are made with metal blades. The blades are rivotted or glued to a slit cut into the handles.

To make the curved scraper the sides are bent up about one-quarter of an inch. The straight scraper's blade is left flat. Handles are carved from a piece of scrap lumber or old gun stock. The curved scraper's handle is about one and one-half an inch thick, two inches long and carved so that it fits comfortably into the user's hand. Two indentations for the index and middle finger are carved into the wood. The straight scraper's handle is about one inch thick and three inches long. The metal blades are glued or rivetted into a slit cut into the handle. 
skins are cleaned on a scraping platform. Some platforms were made from the cut out sections of formica counter tops discarded after installing sinks. The legs are made from three-quarter inch plywood cut about six inches wide, tapering to about four inches wide, and the length of the platform. The legs are screwed or nailed to the top creating a sloping platform. The scraping platform is used with the highest edge closest to the body.(fig. 4)

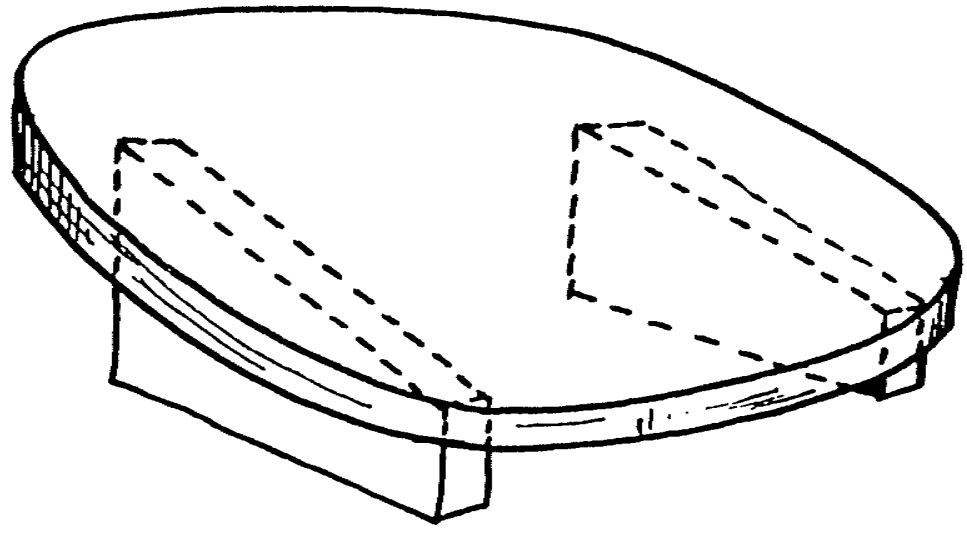

Figure 4. Scraping platform. Sealskins are scraped on a slanted platform.

Traditionally, women used their knees or a flat rock to scrape on, several women showed me scars on their hands which they received when using these 
methods. The scraping platform is safer because the hand that is holding onto the skin is below the front edge, free of the ulu.(fig.5)

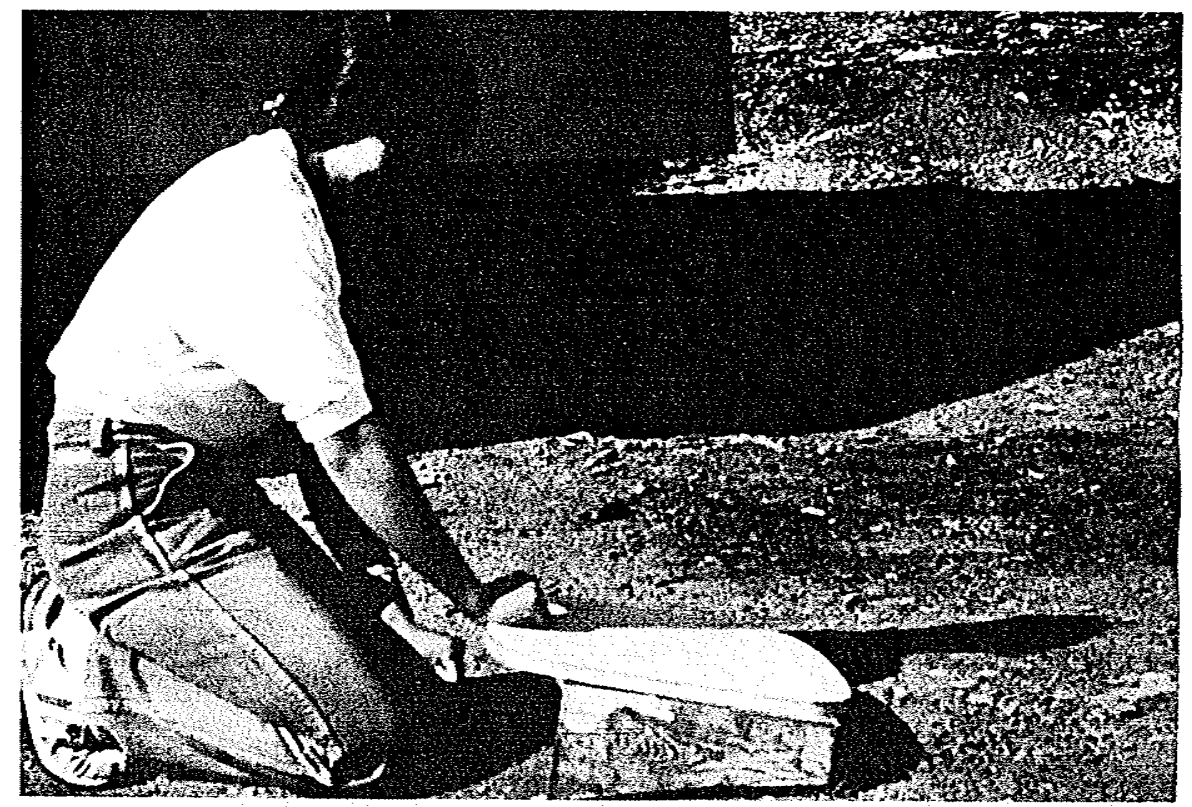

Figure 5. Safe scraping position. Notice the left hand is held free of the ulu.

\section{4 SRIN PREPARATION}

Stefansson's advice was to find a "...family in which there is on hand, already made for one of its members, the garment you want and the size you need" (1945:254). Skin preparation and sewing with skins involve highly skilled and ardorous steps. Sealskin is prepared in one of three main methods: haired, waterproof and freeze-dried. 


\section{IV.4.1 HAIRED SRIN PREPARATION METHOD}

The following method of sk in preparation produces a skin with the hair intact. This skin is warmer than dehaired skins.

\section{IV.4.1.1 REMOVING THE BLUBBER}

The first step of skin preparation is to remove the subcutaneous fat and connective tissue. An ulu, sharpening steel, scraping board, some weights (rocks), and a plastic bag are needed to remove the blubber and connective tissue. Scraping is done in a shady spot on a warm day (over 10C), a sunny spot on a cool day or in the porch. It takes an experienced woman just over half an hour to complete a four and. one-half foot long ringed sealskin.

The skin is placed on a scraping board, hair down, with the nose closest to the scraper's body. A large plastic bag is placed at the lower end of the platform to collect the blubber. A finger is slipped into a hole in the head area and acts to adjust the skin's tension. If the skin slips forward or curls, weights are used to hold the edges down.

The ulu is held in the right hand with the index and middle fingers placed on the blade to regulate the 
depth of each slice. The bevelled edge should be placed next to the skin. A smooth, slicing stroke, about four inches long, is used to scrape off the blubber and connective tissue. One informant said beginners could learn the motion by slicing very thin slivers of homemade bread with an uIu.

The skin is scraped towards the tail, pulling the tail closer as one advances down the seals' back. The scraping platform must be kept clear of blubber to prevent accidental nicking of the skin. Beginners may find the center section easier to scrape than the outside edges near the flipper. The skin is scraped to the protruding flipper and folded over at the under-flipper. A Iongitudinal slit, about three inches long, is made over the wrist joint. The flipper is bent back, the ulu is slipped behind the protruding wrist bone and sliced off. The longitudinal slit is extended to the underbelly so the skin can be laid flat.

Another method is to slice the flipper off flush with the skin. The remaining hole is sewn up after the skin is scraped. Both methods are equally effective, personal preference helps to establish which method will be used.

Scraping continues down to the tail. The top layer of the tail is sliced off and the irregular 
edges around the tail and nose are trimmed. (fig. 6)

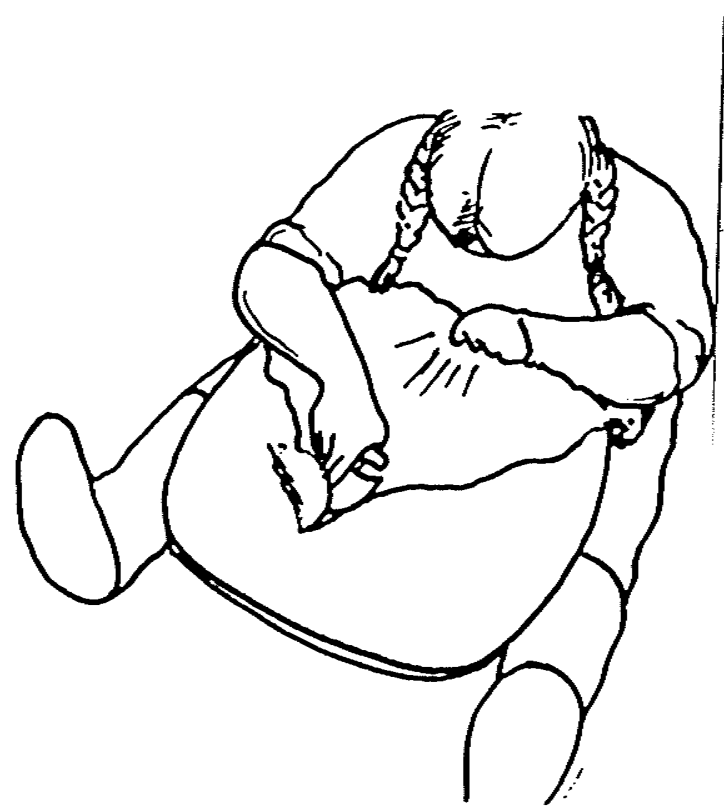

Figure 6. Woman_scraping..a skin. The Top layer of the tail is sliced off with the ulu.

A well scraped skin has an even, light-grey appearance. White sections indicate areas which have not been scraped enough. These areas shrink during drying and are difficult to soften. Dark grey areas are scraped so thin the hair roots are cut, causing the hair to fall out.

IV.4.1.2 REMOVING OILS

To remove the oil, the freshly scraped skin is 
placed, hair down, on the scraping platform and positioned so that the head is closest to the worker's body. A finger from the left hand is slipped through a hole in the head region in order to regulate skin tension. The scraper is pushed over the skin, pressing out oil, shreds of dermis and fat. The hair side is also scraped.

Residual oil is removed by washing the skin in warm, soapy water. Before soap was available skins were rubbed with sand and gravel to remove the oil. In this region skins were not soaked in urine nor could informants recall any of their relatives mentioning the use of urine. In the Igloolik region Manning (1944) found that urine was used to prepare skins.

IV.4.1.3 STITCHING

Holes in clean, scraped skins are sewn up with a number nine, sharp needle and waxed thread or sinew. A knot is made by making a loop in the end of the thread, slipping the needle partway through the loop, rotating the needle three or four times then sliding the loop down the needle to the end of the thread. starting at one end of a small hole or slit, a 
one-eighth inch stitch is taken parallel to the hole's edge. Another tiny stitch is taken on the opposite edge. Every second stitch is tightened enough to make the skin edges meet and roll over slightly. (see fig. 33) The stitches are not pulled so tight that the seam puckers. Stitches which are too loose will allow the seam to work back and forth creating a large hole. Large openings, such as the hole left when the flipper is sliced off flush with the skin, are closed by sewing a row of running stitches around the hole and pulling them tight. This creates a puckered centerpoint rather than a long slit.

Seams are secured by taking three stitches on top of each other, slipping the needle through each loop and running the needle into the skin for about one-half an inch. Haired skins are now ready to be dried.

IV.4.1.4 DRYING

Wet skins are hung over shaded clothes lines, railings or 'pasted' to a shady, outside wall. (fig 7) Skins are left until the hair feels dry. This may take thirty minutes on a hot day or several days during cool, humid weather. Stefansson (1945) states that skins dried in one day during the summer or one 
week in the winter.

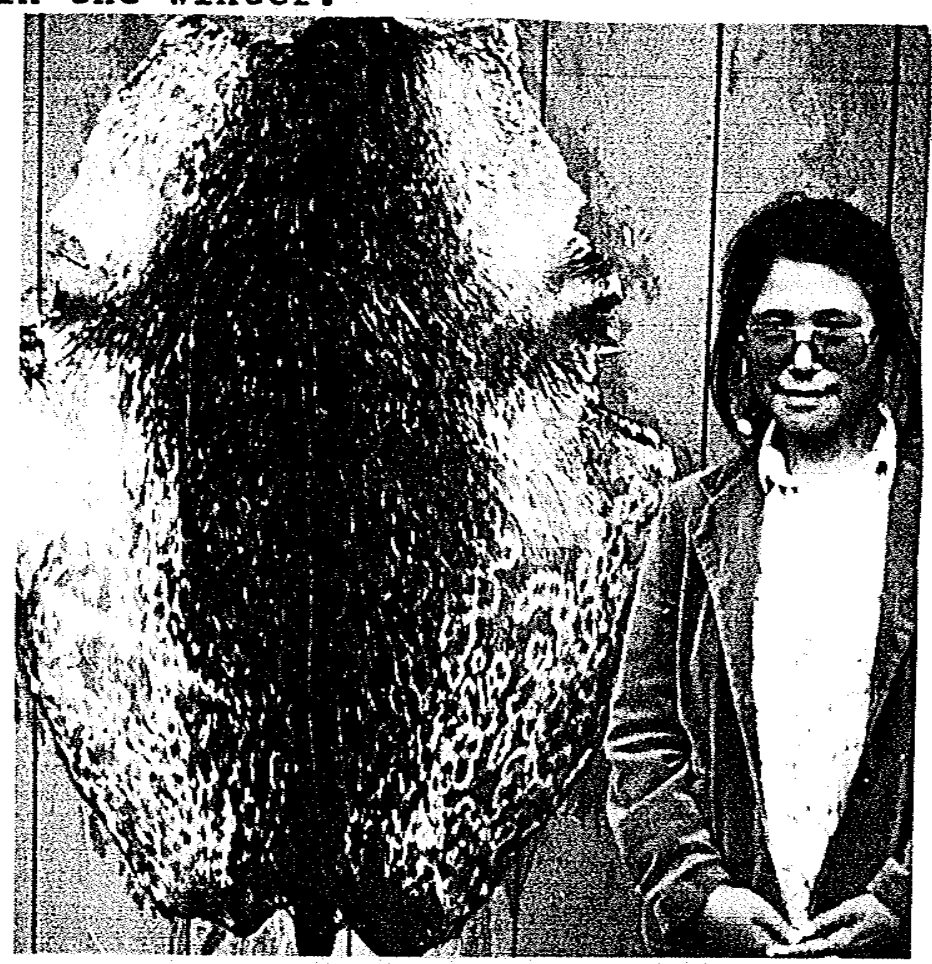

Figure 7. Drying skins. Skins are hung out in the shade to dry.

Skins exposed to direct sunlight on hot days (10 C.) become brittle within half an hour. These over-dried skins can be saved by resoaking them in lukewarm water until they soften and carefully re-drying them.

IV.4.1.5 ALTERNATIVE STEPS

One informant uses an additional step to produce extra soft, clean smelling haired skins with a creamy-white dermis. Salt is rubbed into the dermis, 
the skin is folded together and set in a cool place overnight. The next day ammonia or a brand named cleaning product called "Mr clean" is smeared over the dermis, then the skin is dried and stretched.

\section{IV.4.1.6 STRETCHING}

Skins are stretched onto wooden frames, sheets of plywood or the ground.

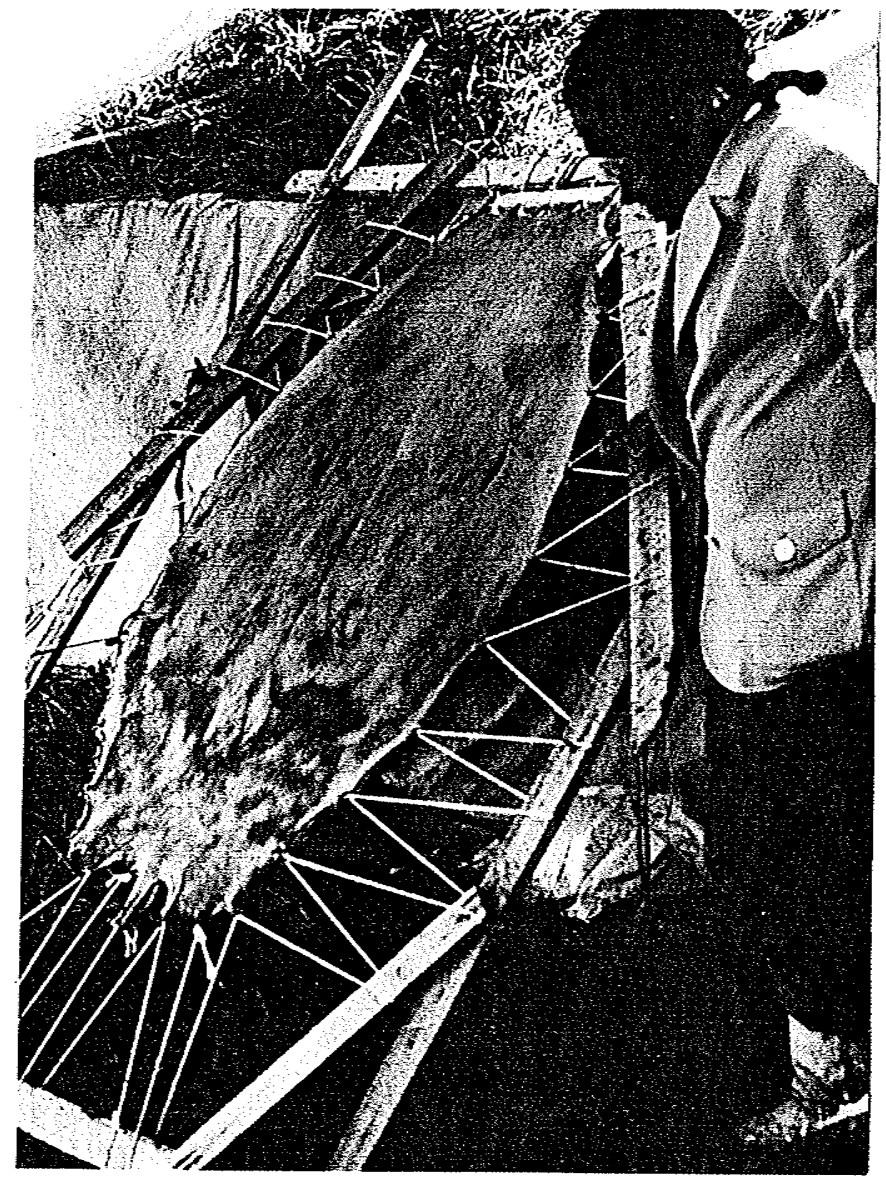

Figure 8. Stretchhing_skins. Skins lashed onto wooden frames are leaned, hair down, against a wall. 
Sealskins are stretched using one of the following methods :

1. They are lashed onto reinforced wooden frames which are leaned, hair down, against a shady wall. (fig. 8)

2. They are nailed, hair down, onto a sheet of plywood. Two inch long nails are nailed through the skins and about one-half an inch into the plywood. The skin is slipped to the top of each nail to improve air circulation.

3. Approximately three dozen sticks, one-half inch in diameter and eight inches long, are used to peg seal skins to a shaded, south facing slope. Air circulation is improved by slipping the skin to the top of each peg. As the skin dries it draws the pegs in, increasing the shrinkage, and producing a skin that is easier to soften than one stretched to a frame or nailed to a piece of plywood. The top right hand side is mounted by lashing, pegging or nailing the skin in a counter-clockwise direction.(fig. 9) The sides are secured with enough tension to form an elongated curve rather than a short, squat outline. Skin tension is tested by poking a finger into the skin, the indentation should remain for a few minutes. An over-stretched skin bounces back immediately, an 
under-stretched skin will not bounce back at all.

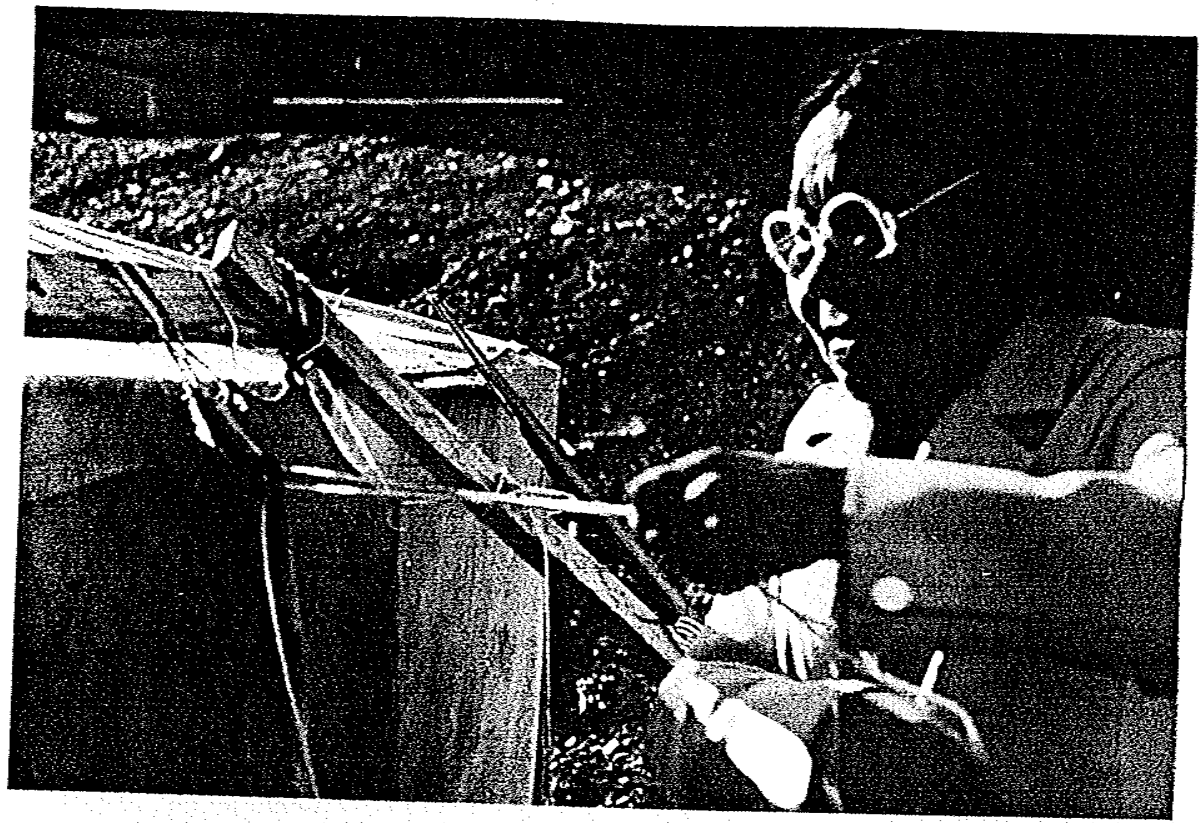

Figure 9. Lashing_skins_to_a_frame. Beginning at the upper corner, skins are lashed on to the frame in a clockwise direction.

When Manning was in the Arctic he dried sealskins by weighting down the corners with rocks and scraping the skin until it was dry. This method produced a "pre-shrunk" skin which shrunk less than skins prepared using alternative methods (Manning 1944). This method was not used in Arctic Bay. Skins that are pegged or lashed to dry have three-quarter inch long slits, spaced every four inches, cut about one-quarter of an inch from the outer edge. Slits placed too close to the edge will 
tear out.

Skins are left out for two to three ary days, over-drying produces brittle skins. Dry skins are removed from the stretching frame and immediately softened. Delays make skins more difficult to soften.

\section{IV.4.1.7 SOFTENING SKINS}

Dried skins are washed in warm, soapy water and hung out to dry. The skins are scraped, stamped and wrung until they are soft.

\section{a) Scraping}

A curved scraper and a hard surface, such as the kitchen or porch floor, are needed to complete this step. The skin is placed, haired down, onto the floor. The worker kneels on the skin, facing towards the tail. The tail is clenched in the left hand and folded towards the body. The scraper is placed under the fold. The scraper is pressed down and the skin is pulled tightly over the scraper. The scraper is worked with the grain and lifted back to the beginning of each stroke. The head and edges are scraped against the grain as it is difficult to get a good grip on the skin otherwise. The skin is rescraped three or four times, taking about forty-five minutes.

Scraping removes the black, oily film on the 
dermis, leaving a yellowy-white color. A good quality scraped skin is pliable and the hair lies in one direction. Disturbed hair grain is dampened and combed until the hair is re-aligned.

b) Stamping Skins

Women continue the softening process by stamping on the skin with their feet. A piece of string is threaded through the slits circumscribing the skin. The string is tightened to form a skin ball, epidermis to the inside.

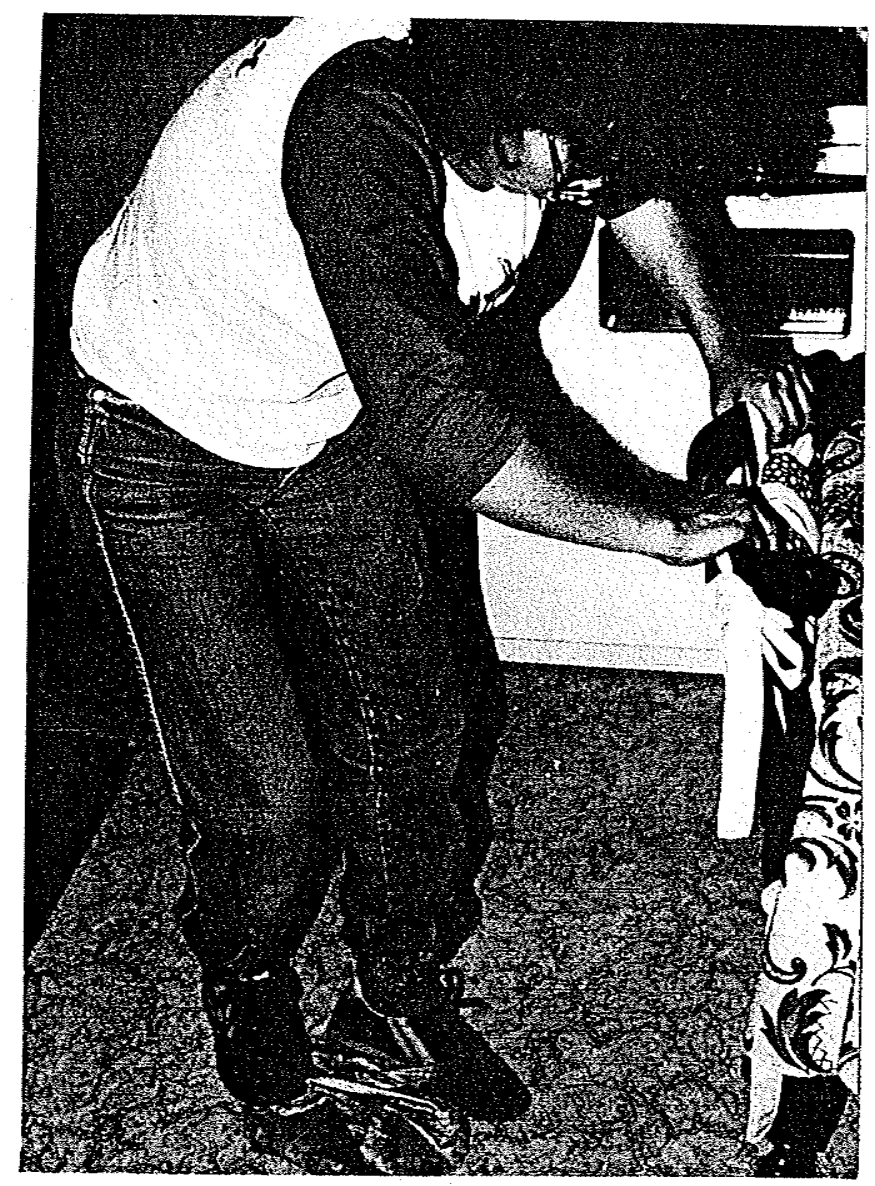

Figure 11. Softening.skins. Skins are softened by stamping them into a small ball. 
Using their feet, women unfolded the skin until it formed a flat, double layer. The skin is reworked into a small ball and back into a large flat bag for about half an hour.(fig. 10) The string is removed and a curved scraper is used to scrape the wrinkles out of the skin.

c) Wringing skins

The third step used to soften skins is to rub and twist the skin between ones fists. A fold of skin, epidermis facing inwards, is clenched between their fists so that the palms are held downwards. The left hand is held stationary while the right hand is rotated. The skin is rubbed and twisted from one area to the next until it has been folded and rubbed in all directions. The skin is now ready to be cut and sewn into kamiks.

\section{IV.4.2 WATERPROOF SRIN PREPARATION METHODS}

There are two types of waterproof skins: white and black skins. Both skins are used interchangeably. One informant told me about a time when her husband needed a new pair of waterproof kamiks. The seamstress did not have enough matching 
material so she made one kamik with a white and one with a black upper section. Men, women, and children use waterproof kamiks made from either type of waterproof skin. Graburn (1969), Hatt (1914) and Turner (I894) stated that shaved skins are waterproof, while the white, dehaired skins are water-resistant. Hatt (1914) and Manning (1944) claim that white-waterproof skins produced by scalding the skin will dry faster than skins prepared by rotting or shaving the hair off.

\section{IV.4.2.1 WHITE-WATERPROOF SKIN PREPARATION}

The white-waterprooof skin preparation method requires the following equipment: a scraping board, ulu, sharpening steel, straight scraper and a container of hot water.

The first step is to remove the blubber and thin layer of dermis using the directions described in section IV.4.1.1. When Ringed sealskin is dehaired, very little of the dermis is sliced off because the skin is thinner than Bearded or Harp sealskin and will wear longer if it is left thicker.

The skin is submerged into a tub of water, hot enough to turn ones' hands red. Some informants use 
hot, salty water as it removes the blood from the skin producing a whiter skin. Water that is too hot will cook the skin, making it useless for sewing as the skin will disintegrate. Water that is too cool will not loosen the hair and epidermis.

The skin is poked and turned for about twenty minutes, more hot water is added as needed. Once the hair is loosened the skin is removed from the water, excess water is squeezed out and the skin is prepared for scraping. This is the same technique used by the Inuit in the Igloolik region (Manning 1944). Freeman (1969) mentions that Pond Inlet women taught this technique to the Inukjuak women in Grise Fiord during the mid 1950's. These women felt this method reduced the need to soften skins by scraping or chewing. Hair and epidermis is also removed by rolling the skin, hair inwards, into a ball and leaving it in a plastic bag overnight. The skin is scraped the following day. Stefansson (1945) mentions a similar method but omits the plastic bag.

Sealskins used to be soaked in blubber for up to a month. When the hair began to slip the skin was scraped.

Hatt (1914) says that skins were soaked in lukewarm water or urine before rubbing the hair off. Arctic Bay informants were not familiar with these 
methods.

In Arctic Bay hair and epidermis is scraped off using a straight scraper. The wet skin is placed on a scraping platform, with the seal head closest to the scraper's body. The scraper is held low to the skin. The hair and epidermis is removed with long strokes. Extra pressure is placed on the left or right corner of the scraper.(fig. 11)

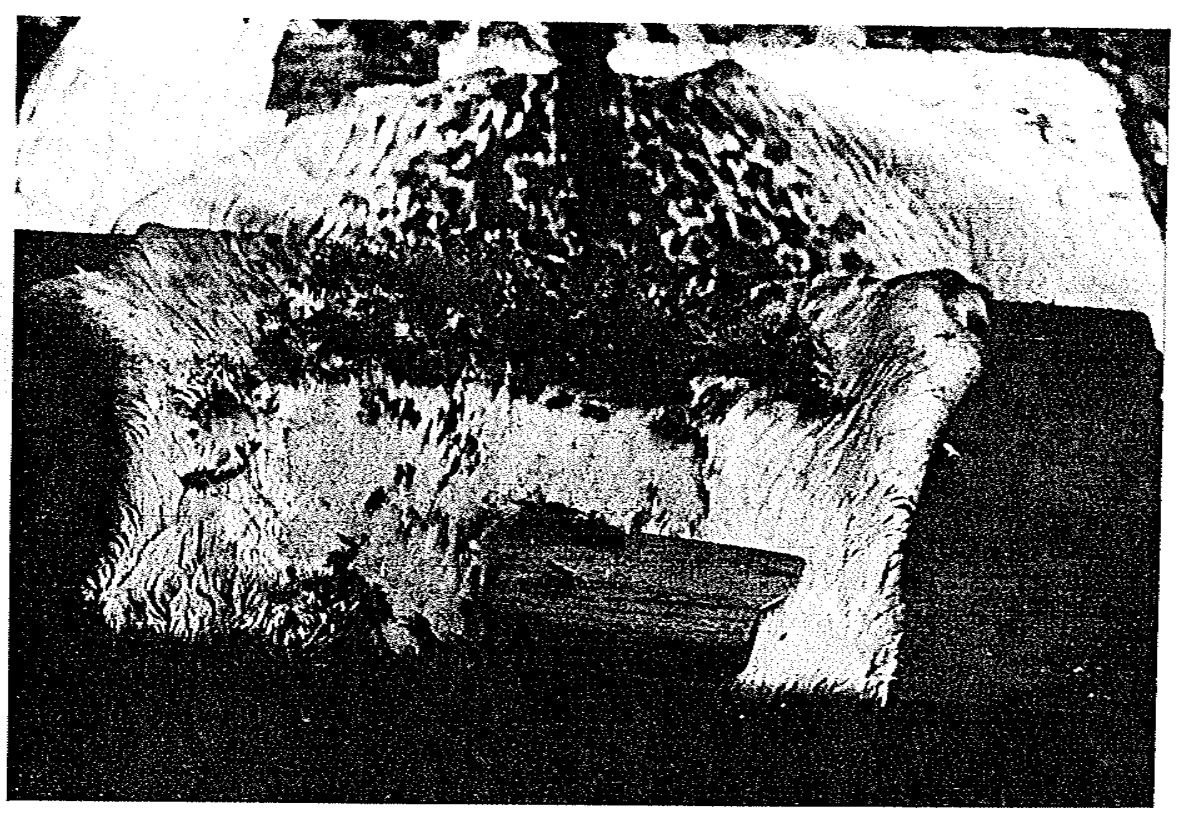

Figure 11. Removing the epidermig. The hair and epidermis is scraped off with a straight scraper.

Sealskins that are difficult to scrape are re-submerged into hot water until the hair is looser. Dehaired skin are then soaked in icy, salt 
water for one or two days to remove the blood. The skin is stretched and softened as described in section IV.4.1.6 and .7.

\section{IV.4.2.2 BLACK-WATERPROOF SKIN PREPARATION:}

A black-waterproof skin is produced by shaving off the seal hair, leaving the epidermis intact. Shaved Barp and Bearded sealskins are preferred for soles as they have thicker skins which are more durable than Ringed sealskins. Uppers are generally made from Ringed sealskins although some people prefer Harp skins as they are stiffer. Each species is shaved in the following manner.

IV.4.2.2.I SHAVING SKINS:

Women use an ulu, sharpening steel, scraping platform and plastic bag to shave sealskins. An ulu is used to slice off the blubber following the directions given in section IV.4.1.1. The layer of dermis is not sliced off at this time. The hair is shaved against the grain using a very sharp ulu.(fig. 12) As shaving proceeds the scraping platform is kept clear of fat and hair to prevent nicks. Slits are cut along the skin's edge in order to hold onto the skin. 


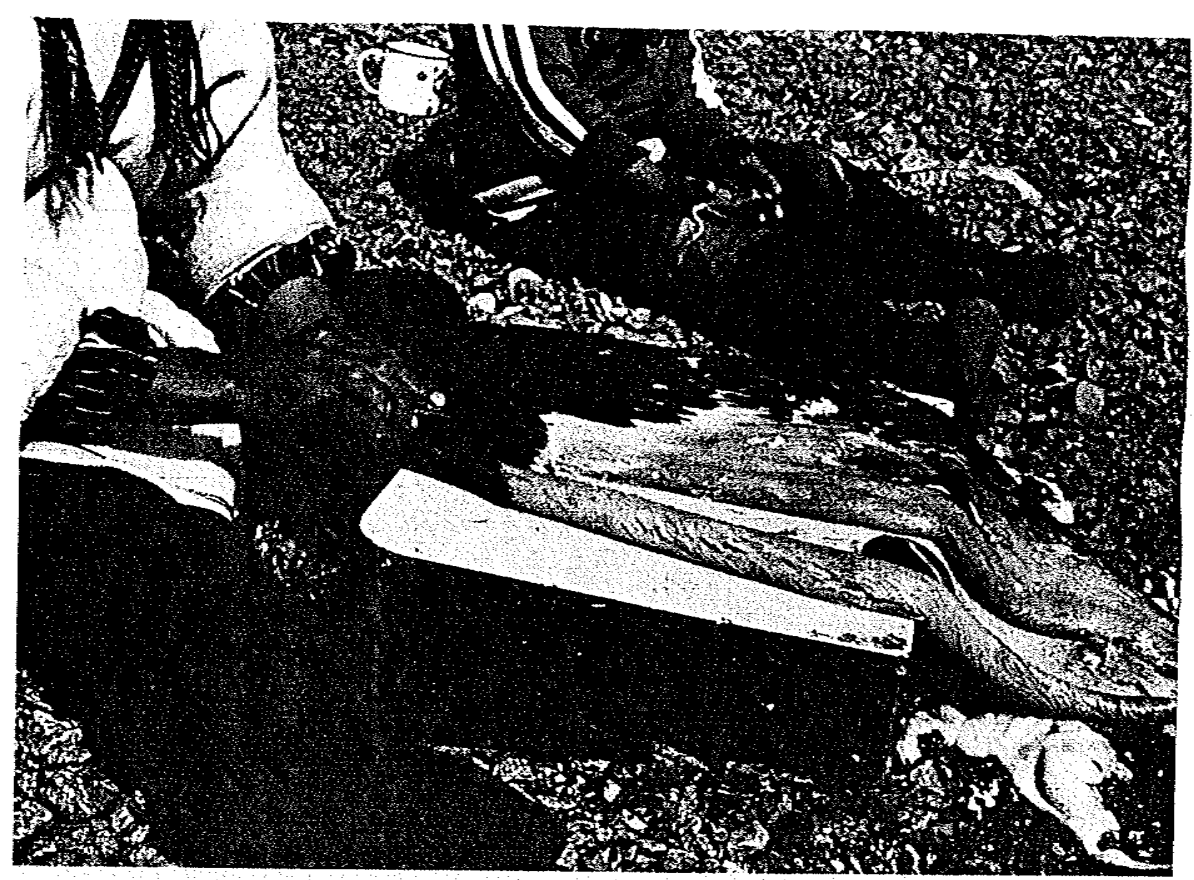

Figure 12. Shaving sealskins. Sealskins are shaved with a sharp ulu.

Shaving requires concentration, practise, strong. arms and time. Bearded, Harp and large Ringed sealskins are divided in half enabling several people to shave one skin, reducing the shaving time to one afternoon. Unfinished skins are frozen or left overnight and shaved the next morning.

The shaved skin is flipped over to remove the connective tissue, improving the skin's elasticity. Uneven bristles are trimmed and leftover hairs are removed. The skin is then stretched to dry following the directions given in section IV.4.1.6. 
IV.4.2.2.2 SOFTENING SHAVED SRINS

Shaved, Ringed sealskins are removed from the stretching frame and softened as described in section IV.4.1.7. Bearded and Harp sealskins are left unsoftened until they are cut into kamik pieces.

\section{IV.4.3 FREEZE-DRIED SKIN PREPARATION}

A satiny-white, dehaired, freeze-dried skin is used primarily for decorative kamiks. White-waterproof skins are prepared by following the directions up to the stretching procedures (see section IV.4.2.1). Satiny-white skins are made by stretching the skins in early spring. Once the skin freezes it is removed from the frame and hung outside for about one week. Mechanical and chemical action caused by long hours of sunlight, cold temperatures, and blowing snow bleaches the skins. If the weather warms to above freezing, skins become discolored. Freeman (1969) states that Pond Inlet women introduced a new method to Inukjuak women in Grise Fiord. Skins were dipped into scalding hot water or soaked in urine for two to three days. After soaking they were stretched, frozen and hung up in the early 
spring sun. This method is not used in Arctic bay. Haired, water-proof and freeze-dried skins are stored in a cool, dry place. Traditionally, skins were cached under a pile of stones (Bruemmer 1971). When a new pair of kamiks are needed, skins are selected from the storage shed or traded with other seamstresses.

There are two main types of sealskin boots: winter and spring kamiks. Each type is constructed using a unique combination of skins prepared by the methods discussed in section IV.4.1, IV.4.2, and IV.4.3. The following section discusses the pattern development, layout, cutting techniques, assembly instructions, maintenance and end uses of winter and spring kamiks. 


\section{5 WINTER RAMIR CONSTRUCTION}

During winter the most serious problem affecting Inuit hunters is dampness and the resultant loss of insulation in their clothing. Perspiration, condensation and wet travelling conditions are factors which make the feet the most difficult portion of the anatomy to keep dry. Sealskin is porous therefore it allows body vapors to escape which reduces the amount of moisture collected inside sealskin kamiks. (Riewe 1975, Stefansson 1945). Haired skins are a good choice for the upper section of winter kamiks. The skin is porous, readily available and warmer than dehaired skin.

Winter kamiks have three main parts: an upper, instep and sole section. The upper section is made from haired skin, the sole is made from waterproof skins, and the instep is made from waterproof or freeze-dried skins. The following section discusses each step of the construction process for the upper section, instep and soles of winter kamiks. 
IV.5.I UPPER SECTION

The upper section pattern is cut out and a decorative inset is then designed, assembled, and inserted into the upper section.

\section{IV.5.1.1 PATTERN DEVELOPMENT}

Kamik patterns are developed by using the hand span as a measuring tool. One hand span is the distance between the end of the thumb and middle finger, with the hand held relaxed.(fig.13)

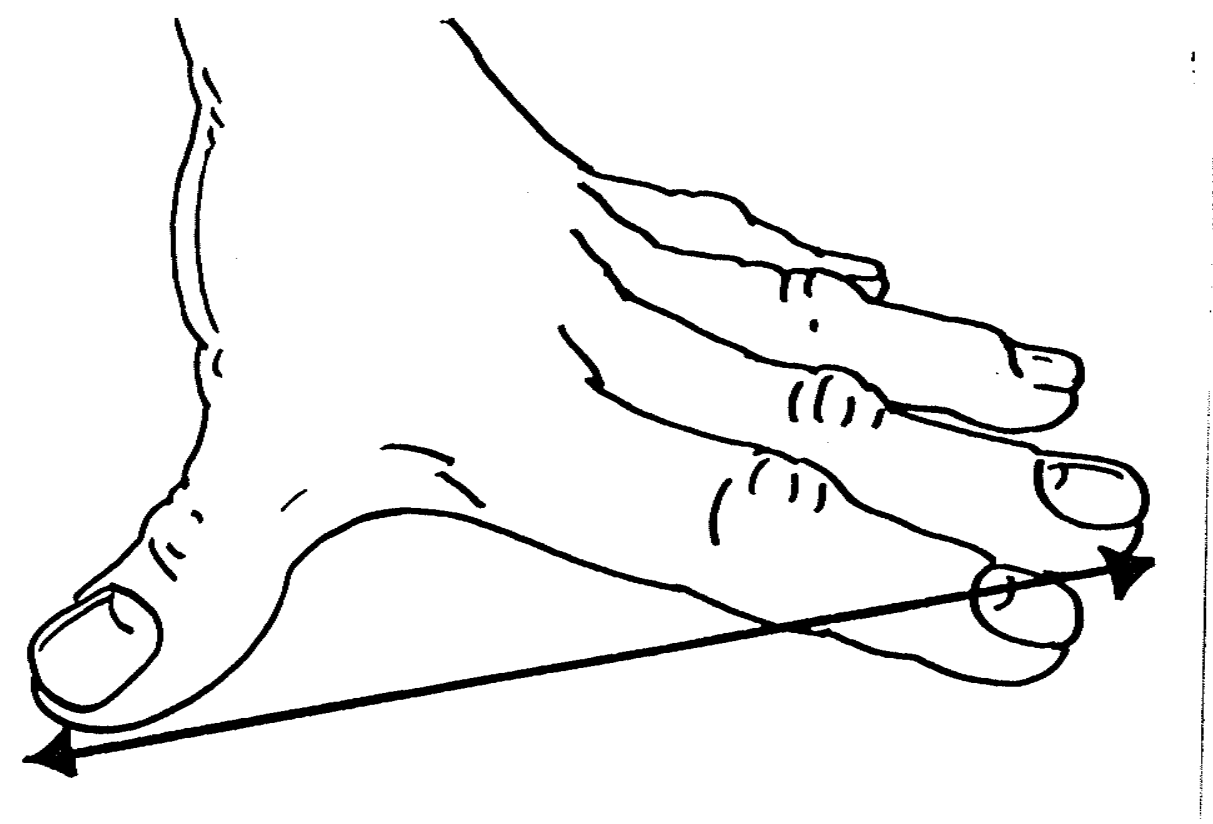

Figure 13. A_hand_span. One hand span is the distance between the tip of the thumb to the tip of the middle finger. 
The hand measurements given throughout this thesis refer to the person's hand for whom the pattern is being made. Patterns developed for someone else's foot size are made with that person's hand span or an outine of their foot. Informants under thirty years old rarely know how to create patterns using the hand span method. They use paper patterns developed by elders. Experienced respondents can just look at a person's foot and cut kamik pieces out, using their own hand span. Informants stressed that experienced seamstresses do not follow the pattern used by other family members. They create their own personal style by combining ideas from several other sewer's kamik styles. Each woman varies the height, width, length, and number of pleats to create a personalized kamik. The following directions make a basic pattern which. can be altered in many ways.

The haired kamik upper section is made by placing one's thumb at the proposed center front line (a) and measuring one hand span across to the center back line (b). A mark is placed below the knuckle which connects the index finger to the hand, for future reference (c). The center back is made one thumb width lower (b-d) than the center front mark. The line from the center back to the ankle bone (d-e) curves to below the ankle bone. The ankle bone point 
(e) is perpendicular to and about one and one-half thumb widths lower than the knuckle mark (c). The line from the ankle bone (e) curves sharply up terminating at the center front (a).(fig.14)

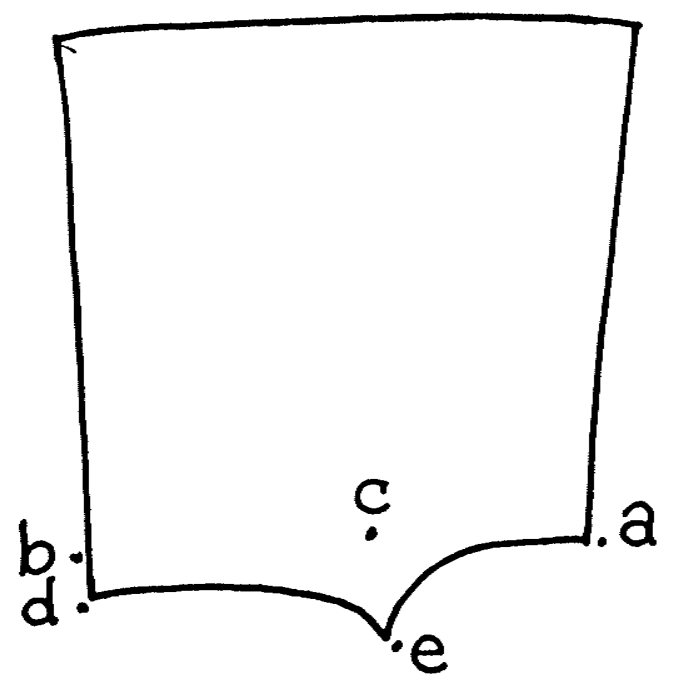

Figure 14. Upper_section_pattern. The cutting Iine of the upper section's pattern curves from the center back (d) down to the ankle bone marking (e) and back up to the center front position (a).

Variations are created by varying the measurements. The distance between the ankle and center back is made up to one and a half knuckles ( 1 $1 / 2$ ") shorter, creating a tighter fit around the ankle (line d-e). The center back point (d) is placed 
between a point one thumb width lower than, to one thumb width higher than point ' $b$ '. These alterations make the upper section more or less horizontal to the ground. Lengthening the distance across the instep (e-a) creates more pleats across the front of the instep. Op until the 1970's few pleats were sewn into the center front instep area, creating a stove-pipe like appearance in the upper section of the kamik. Today, more pleats are used, creating a wider silhouette.(fig.15)
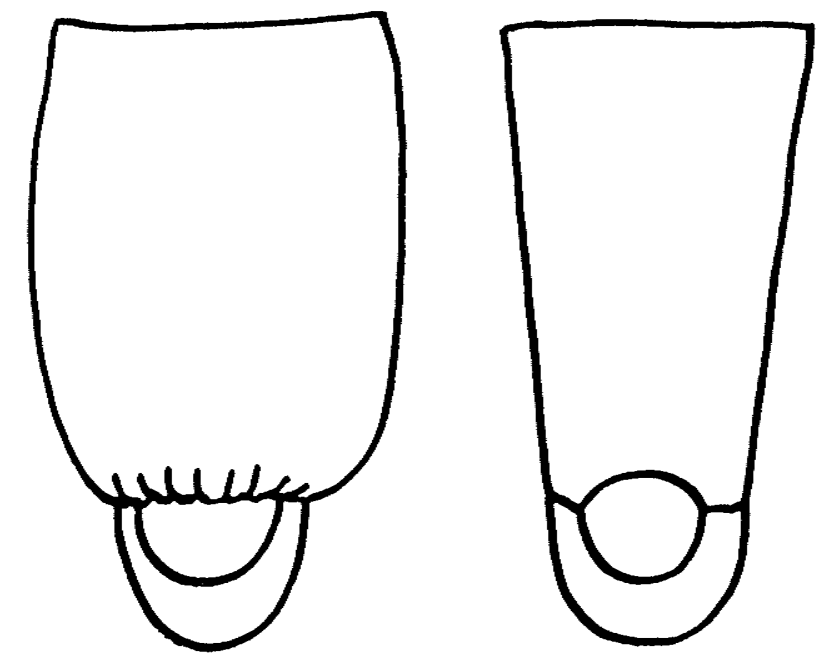

Figure 15. Kamik_silhouettes. A fuller silhouette is created by adding more pleats to the upper section.

The height of the upper section is measured one and one-half hand spans high. A two inch wide band 
is sewn onto the top and a three-quarter inch wide fabric casing is sewn to the band.

The upper edge of the upper section is one hand span plus one half the length of the middle finger wide. This measurement is made with the thumb at the center back fold Iine.(fig. 16)

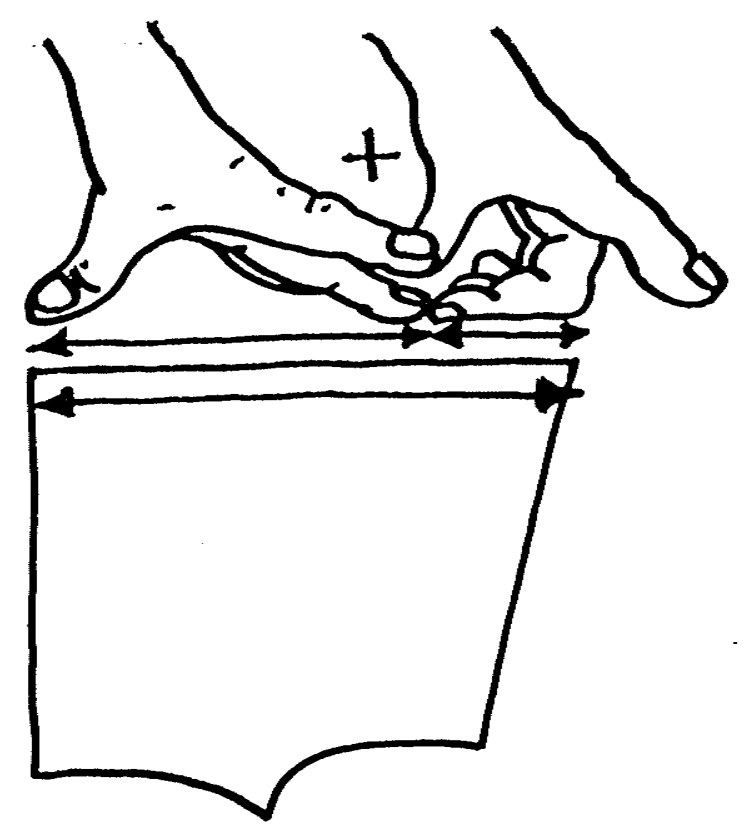

Figure 16. Patttern for_upper_edge_of_upper_sectition. Extra width is added to the top of the Upper section, at the center front or center back seam line. and amount of pleats, to create a personalized kamik. 


\section{IV.5.1.2 INSETS}

Traditionally, kamiks had geometric patterns which ran vertically down the front on men's and horizontally around the top on women's kamiks (Freeman 1978).(fig. 17) Reasons for sexual differences remains a mystery to the informants. Several sewers support the theory that traditional male designs are a statement of the wearer's masculinity.

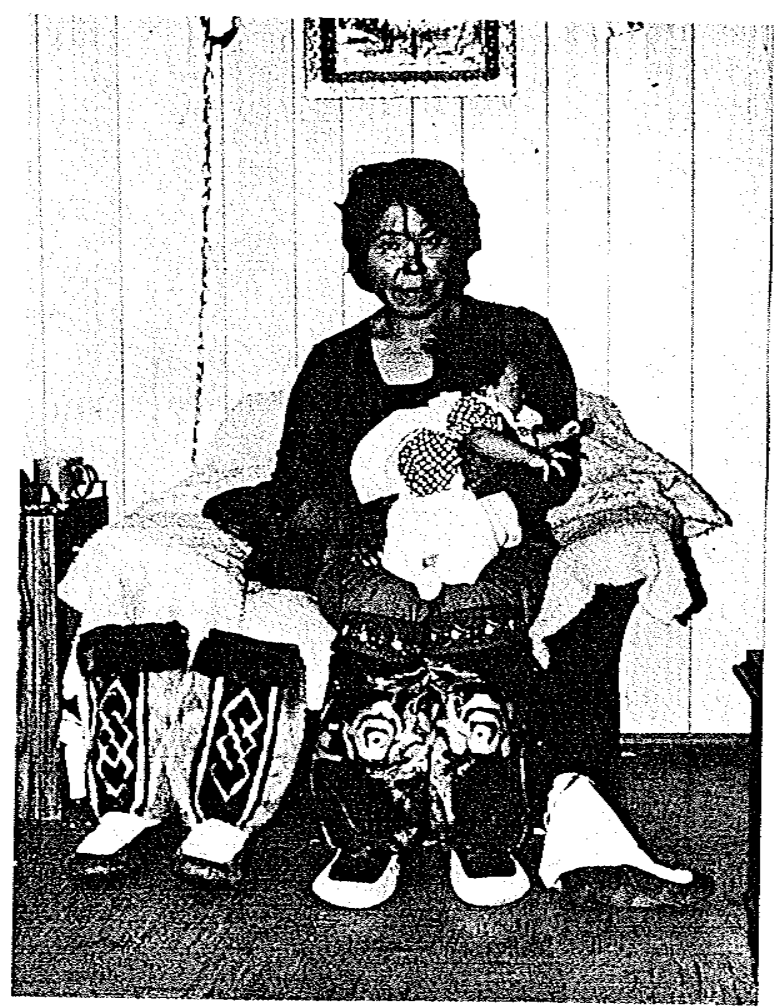

Figure 17. Desighns_on_mâle_and_femalle_kamikgs. Male designs run vertically and female designs run horizonatally around the kamik. 
Inset designs have changed relatively quickly over the last thirty years. Simple geometric designs were used until the $1950^{\prime}$ 's. In the 1960's a gradual increase of intricate geometric shapes and flowers were common. By the $1970^{\prime}$ 's an increasing number of tiny insets were used in animals, logos and letters. In the past few years, names have also become a popular form of decoration. Complicated design insets do not always follow the vertical-male or horizontal-female tradition.

Once the inset and upper section are designed the haired sealskin is prepared for cutting. IV.5.1.3 PREPARING HAIRED SKINS FOR CUTTING

The haired skin is removed from storage, washed. in a basin of warm, soapy water, rinsed and hung in a shaded place to dry. The skin must be watched carefully as it takes less than half an hour to dry on a warm, sunny day. A dry skin is pliable, over-dried skins are stiff, brittle and unusable.

IV.5.1.4 PATTERN LAYOUT

The upper section pattern is drawn on to the dermis. Traditional male kamik patterns are placed so 
the centerfront seam runs parallel to the silver hair. The darkest hair is at center back and the lightest hair at center front. Pieces are placed with the hair running from top to bottom, equal distances from the center back line. The upper section should have equal proportions of silver and black on the right and left boot.(fig. 18).

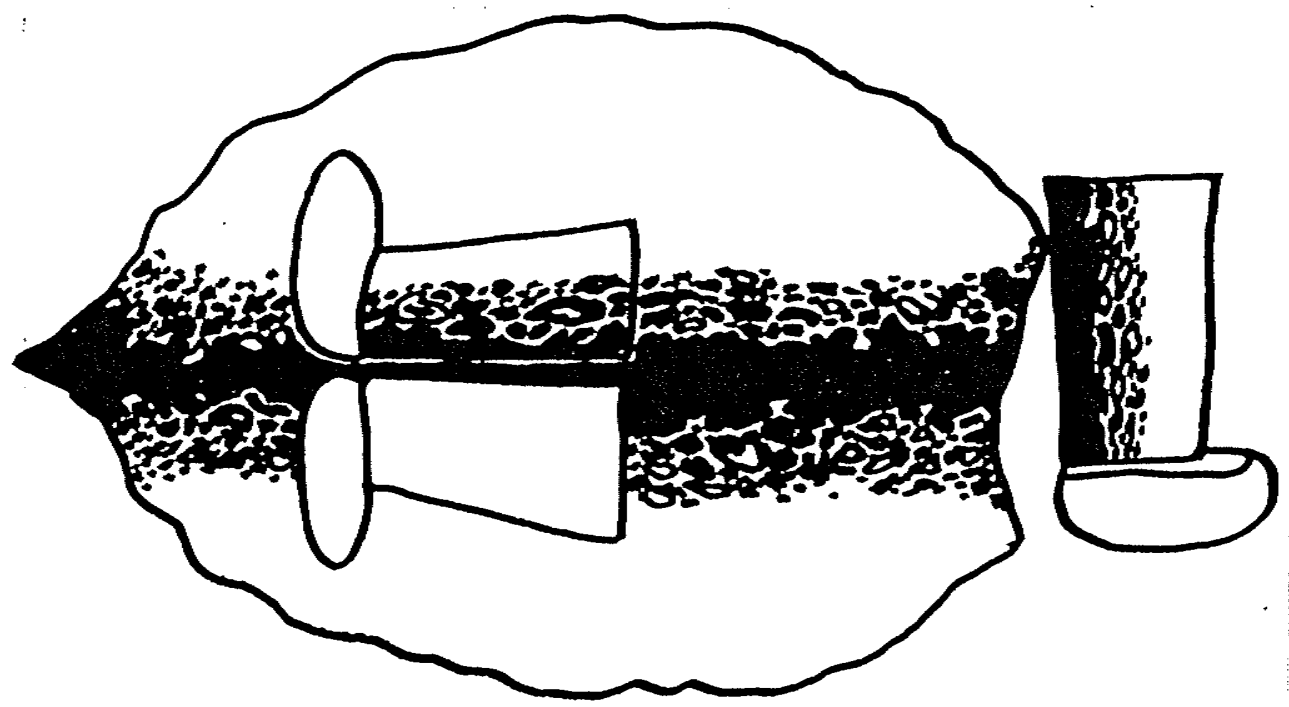

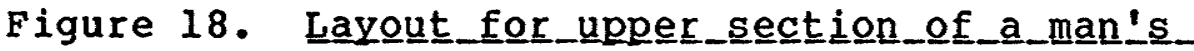
kamik. Male upper sections are laid out so the hair direction runs down the kamik, towards the foot.

The upper sections of traditional female kamiks are placed so the hair points horizontally around the kamik. The left kamik's hair direction is opposite to the right kamik. If the right kamik's 
hair travels in a clockwise direction, the left

kamik's hair travels in a counter-clockwise direction or vice versa. The pattern is positioned with the silver hair running parallel to the upper casing and the darker hair covering the ankle. (fig. 19)

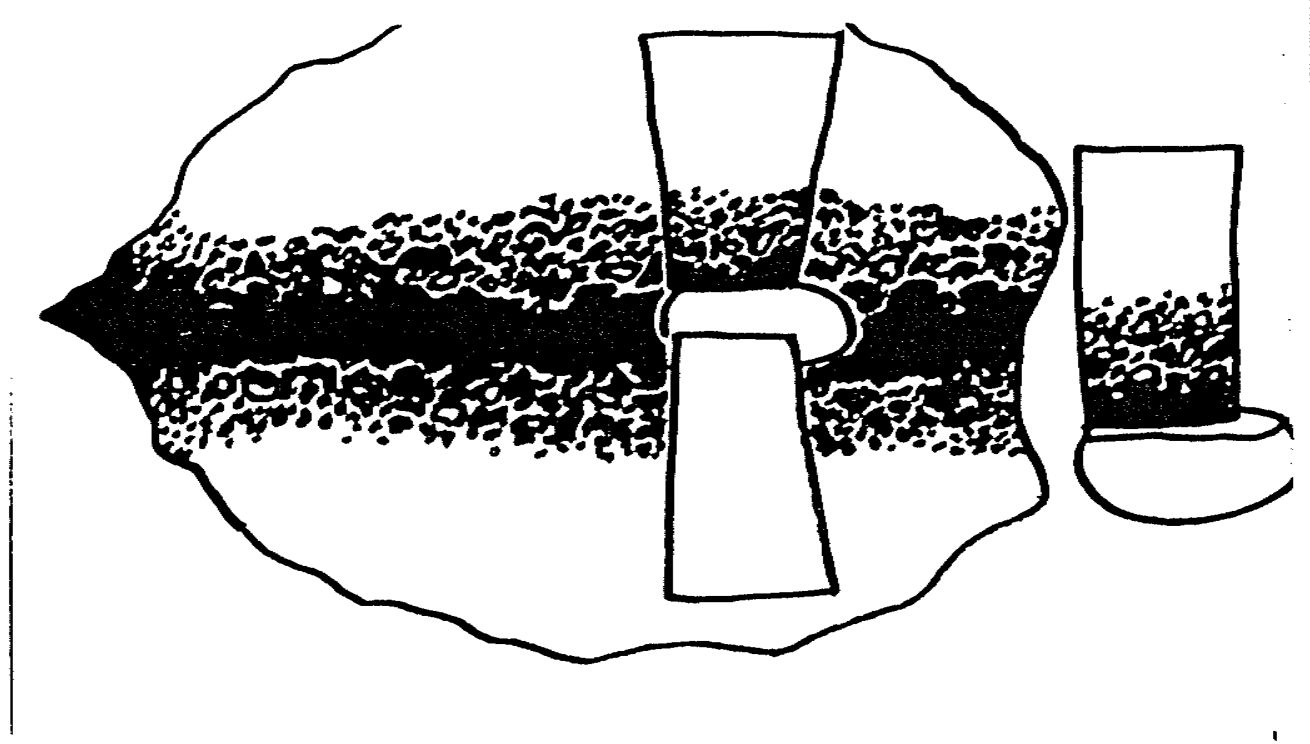

Figure 19. Layout_for_upper_section_of_ą_woman's kamik. Female upper sections are laid out so the hair direction runs horizontally around the boot.

IV.5.1.5 INSET LAYOUT

The inset is positioned so the hair direction on the inset will match the rest of the upper section. The under-flipper hair grows in every 
direction, care must be taken in order to match hair direction. Hair from the under-flipper area is very light and used to create a contrast with the darker hair found on the seal's'back. A one-eighth inch seam allowance is added to each piece before cutting. The same pattern is placed on the upper kamik section and drawn one-sixteenth of an inch smaller to allow for a seam allowance.

\section{IV.5.1.6 COTTING AND ASSEMBLING INSETS}

Haired skin upper sections and insteps are cut from the dermis side with a sharp ulu. Care is taken to cut only the skin, not the hair.

\section{IV.5.1.7 ASSEMBLING WINTER KAMIKS}

Traditionally, insets were sewn into a panel and inserted into the upper section. Contemporary decorative insets are sewn directly into the upper section. Once the inset is installed the center back seam is sewn. A band is sewn to the top edge of the upper section. A one and one-half inch wide strip of fabric is stitched to the band, folded over, and stitched to form a casing. Two slits, about one inch apart, are cut into the outside of the casing and 
reinforced with bottonhole stitches. A sealskin thong, or four-strands of yarn braided into a tie-string, is threaded through the casing. One end of the tie is inserted into the casing through the left opening, threaded around to the right, passing the left opening and exiting through the right opening. This threading technique was also described by Manning (1944) and Riewe (1975). When the tie is tightened the gathers form evenly around the casing, creating a water tight seal. Skin boots made by Indians living in the sub-arctic generally have one slit.
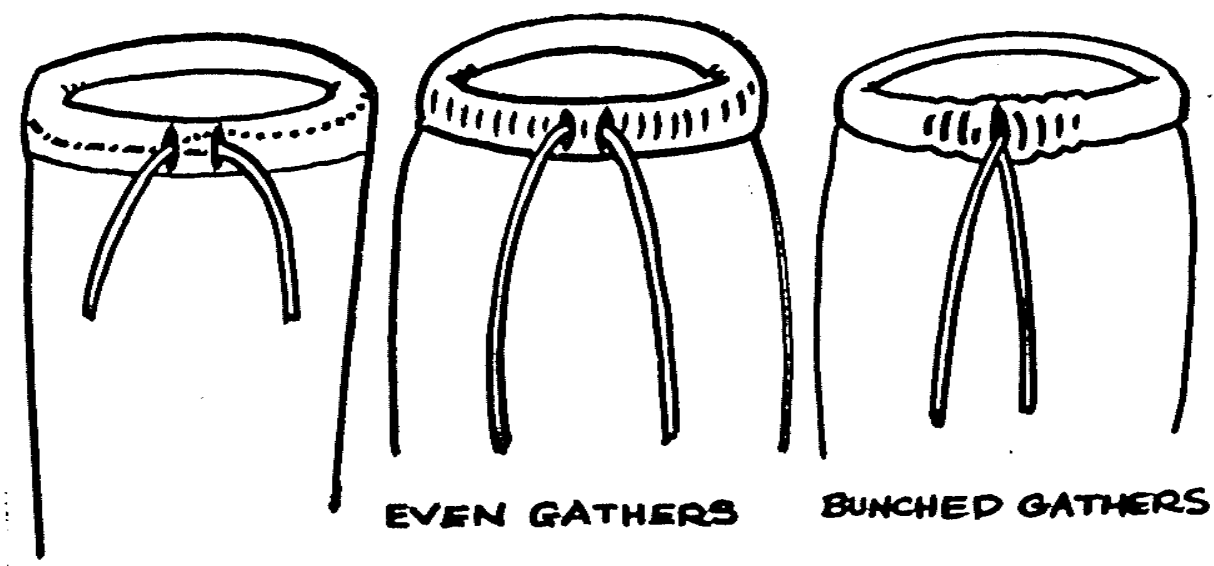

Figure 20. Kamik﹎casing using two openings produced even gathers. 
When the tie is tightened on the style with the single slit, the gathers bulge up at the slit instead of gathering evenly around the casing. Inuit sewers place the slits at center front, center back or along either side depending on individual preference.(fig. 20)

Kamiks are assembled using strong thread, sharp needles and tight stitches. The following subsection discusses these essential parts of kamik production.

IV.5.1.7.1 THREAD

Two main types of thread are used to sew kamiks today. These are waxed thread and sinew (dried animal tendons). Spooles of cream-colored "artificial sinew" are marketed by Irografts Ltd, Ohsweken, Ontario. The Hudson Bay Company supplies Arctic Bay with this nylon thread. A white, waxed, number seven polyester lacing twine is marketed by Leckie's, Halifax, Novia Scotia through the Hudson Bay Company. The "artificial sinew is preferred-because it does not fray as easily as number 7 polyester lacing twine. However, Irocraft's product is often not available. During times of shortages Leckie's product is used on children's kamiks. Adult's winter kamiks are sewn with caribou sinew or Irocrafts" "artificial sinew". 
Sinew is preferred over purchased thread but is not always available.

Waterproof kamiks are sewn with sinew because it swells when wet, filling the needle holes made in the skin. Sinew is also tapered to a fine point, allowing a finer needle to be used so smaller holes are made.

Excess meat is stripped and chewed away from narwhal, caribou or seal tendons before they are washed and laid out on a board to dry. Hatt (1914) and Manning (1944) have documented the same procedure. Once the tendon is dry the strands of sinew are separated, wound around one's palm and stored in a cool, dry place.

Narwhal tendons are about three feet long and look like a heavy, nylon fishing line. This light-tan filament is split into thread-like strands of sinew. (fig. 21)

Caribou tendons are about one and one-half feet long. They are collected from each side of the backbone and back of the legs. (fig. 21)

Wilder (1976) states that Alaskan sewers use beluga sinew, it is stronger than caribou sinew. Women in Arctic Bay do not use beluga, however, occasionally, they do use seal sinew (Hawkes 1916). 


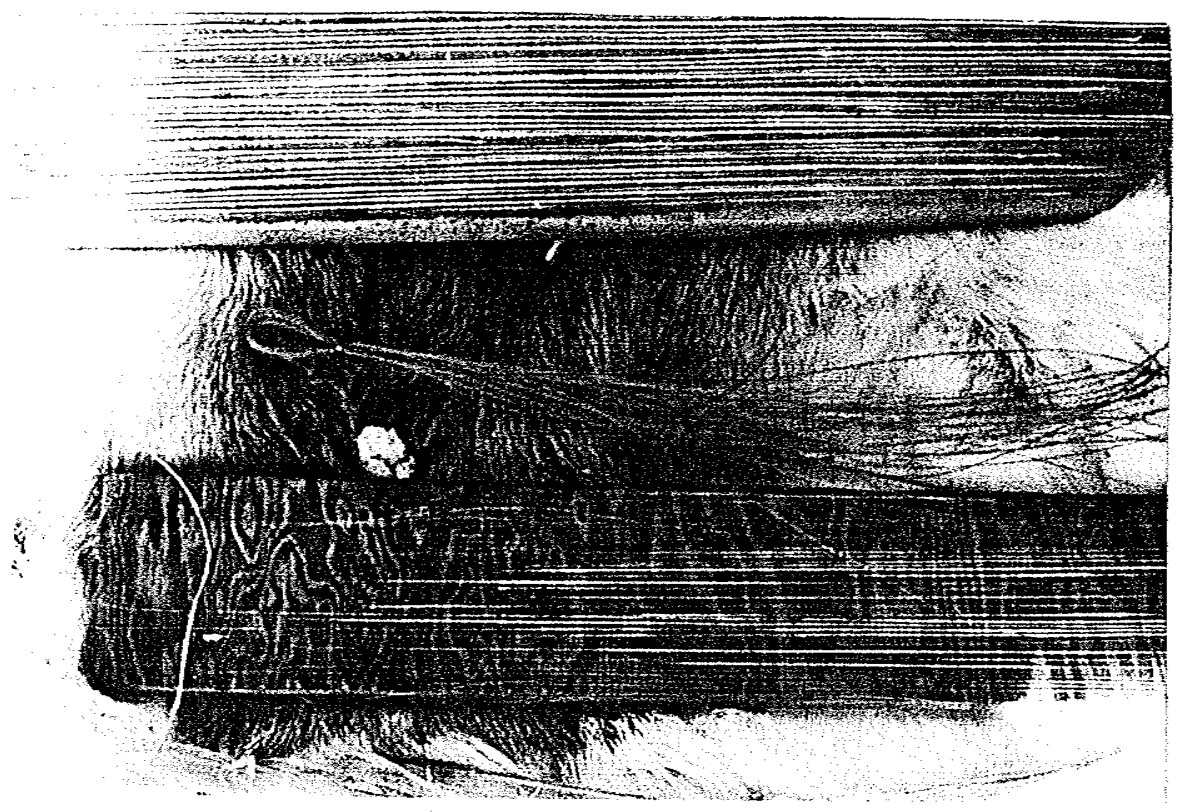

Figure 21. Narwhal__tendons_are_dried_and_used_for thread. Narwhal sinew is like heavy fishing line,

\section{IV.7.1.7.2 NEEDLES}

Several informants recalled making and using bone needles. A piece of caribou fibula was sharpened to a fine point and a slit was cut into it for an eye. Steel and ivory needles were also used in the past according to Hatt (1914) and Taylor (1964). Brass-eyed needles are used today. They are substituted with steel eyed, number nine sharps when 
brass-eyed needles are unavailable. Triangular, glover needles are used for stitching reinforcement rows through the crimping.

Thimbles were made by cutting a one-half inch wide ring of sealskin and slipping it over the index finger (Batt 1914, Turner 1894). Today, purchased metal thimbles are used. My informants also use a strip of sealskin slipped over their baby finger to protect the finger from cuts caused by the thread.

\section{IV.5.1.7.3 SEWING HAIRED SRINS}

Each kamik piece is rubbed, twisted and flattened until it is pliable. Then the pieces are positioned right sides together, using the index finger and thumb to press the hair away from the seam allowance. Hatt (1914), Manning (1944) and Pharand (1975) "simply state that the pile is pushed away from the cut edge and overcasted together. My informants added that the seam allowance and thread are moistened and the thread is knotted before beginning to sew. The thread is knotted by passing the needle through a loop made at the blunt end of the sinew.

Honigmann (1962) said that an extra length of thread was added by splitting the new strand into three, braiding it for about one inch, and twisting 
and plaiting it onto the remaining short piece. Stitching was then continued. This method of connecting threads is not used by women in Arctic Bay. When they are getting close to the end of their thread they end off with a knot and begin with a new thread.

Seams are stitched together with over-cast stitches, one-eighth of an inch deep and one-sixteenth of an inch apart. The stitches are pulled tight as loose stitches will cause the seams to shift, wearing the thread against the needle holes. Seams are sewn from right to left, secured by tying two knots and burying the thread into the skin. Women flatten the finished seam by pressing it with their thumb and gently rumpling it with their palms.

IV.5.2 WINTER KAMIK'S INSTEP AND ANRLE STRIP

Winter kamiks have a tongue-shaped instep and a long narrow strip surrounding the ankle. These pieces are made from waterproof or freeze-dried skins. Freeze-dried skins are used for fancy kamiks while waterproof skins are used for hunting, travelling or playing kamiks. 


\section{IV.5.2.1 PATTERN DEVELOPMENT}

The length and silhouette of the instep varies with personal taste and the sole's length and width. (fig. 22).

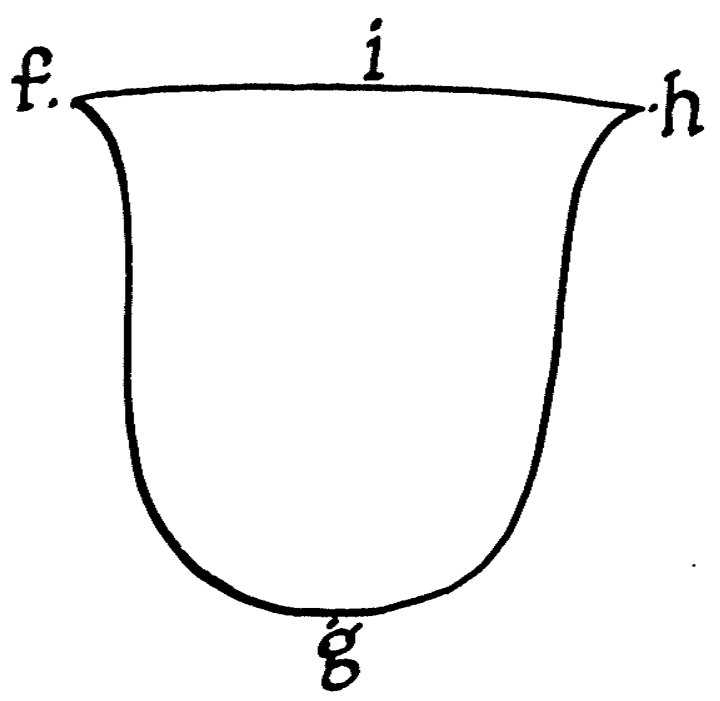

Figure 22. The instep pattern. The instep width $(f-h)$ and length $(f-g)$ have individual variations.

The length of the instep $(i-g)$ is determined by measuring the distance from the base of the thumb to the tip of the index finger and adding one index finger nail width. This distance can be longer or shorter depending on how long the sole is and how much the sewer wants the sole to extend over the top of the 
toe. The distance across the instep $(f-h)$ is measured by cupping ones hand and measuring from the thumb base to the tip of the index fingers.(fig. 23)

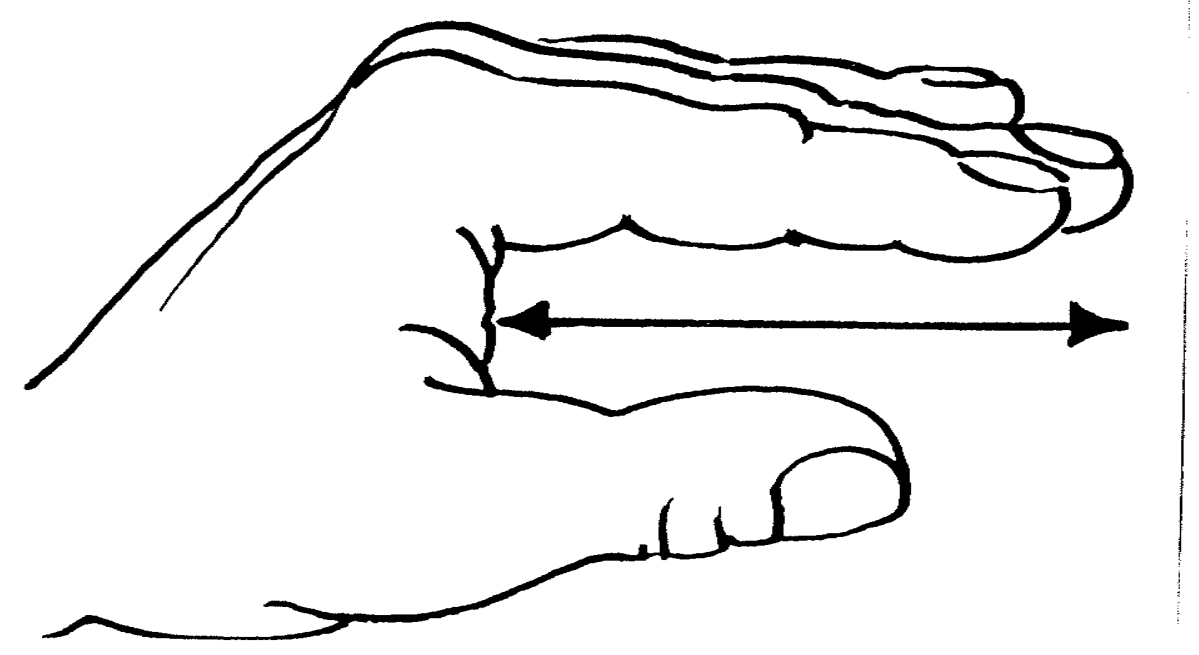

Figure 23. The_cupped_hand_position. The hand is held in a cupped position to measure the instep width.

The long narrow strip used in winter kamiks is one thumb nail wide. It is cut twice the distance between the ankle bone and the center back $(b-c)$ of the upper section. The ends are cut at an angle determined by the sewer. The angle that is used affects the positioning of the instep but all angles result in a comfortable boot. I was taught to cut the strip at a forty-five degree angle from the sole edge as illustrated in figure $24 \mathrm{~b}$. 


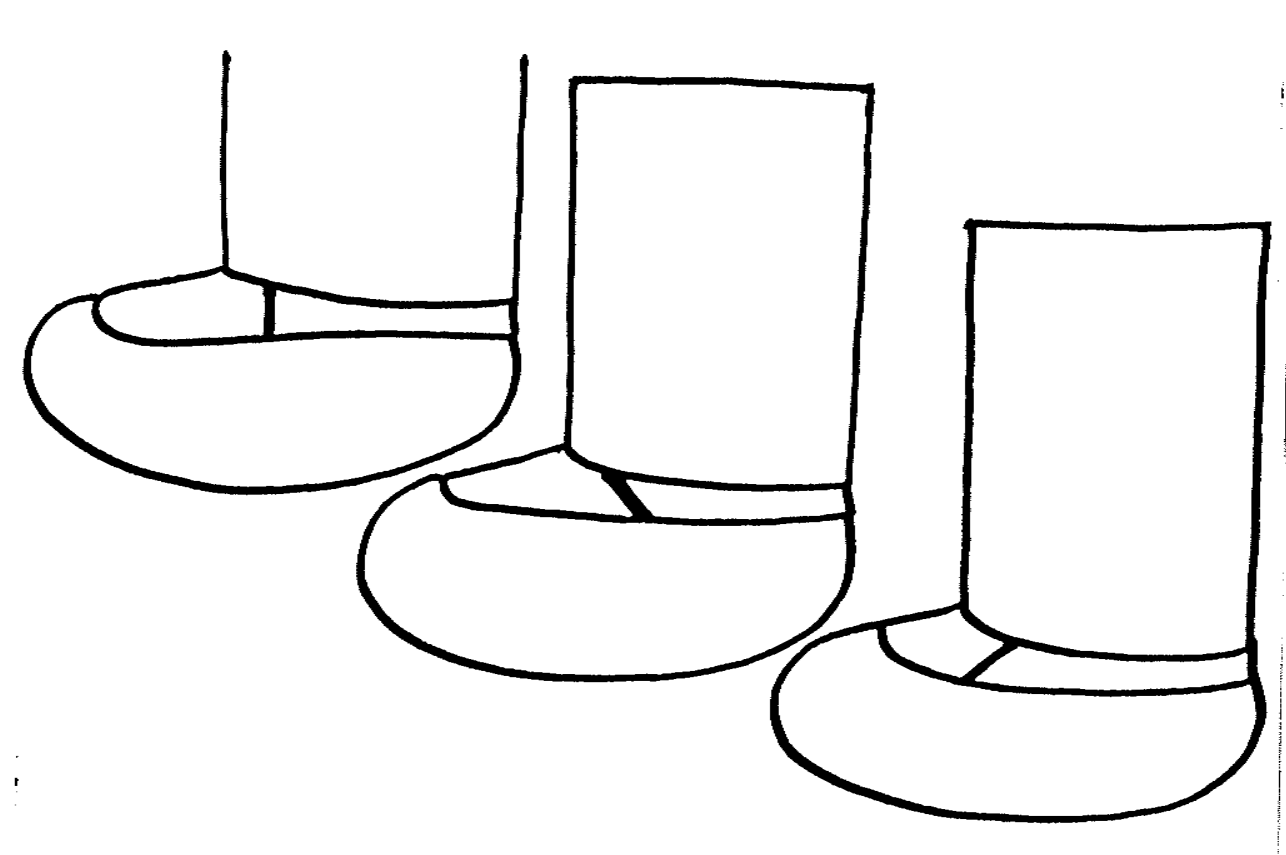

a

b

C

Figure 24. Three different_instep_seams. Instep seams vary 135,90 , and 45 degrees from the sole edge.

IV.5.2.2 LAYOUT AND CUTTING

When a sealskin is wet it stretches more in length than in width. Patterns are placed with the hair grain travelling across the instep and down the length of the ankle strip. Figure 25 describes this layout, using a skin with the hair left on to illustrate the direction of the hair grain. The inset is actually cut from dehaired skins. The grain can be determined by looking for rows of scales running parallel to the crosswise grain. This is important to 
note if one is using scraps of material and the head or tail end are not distinguishable.
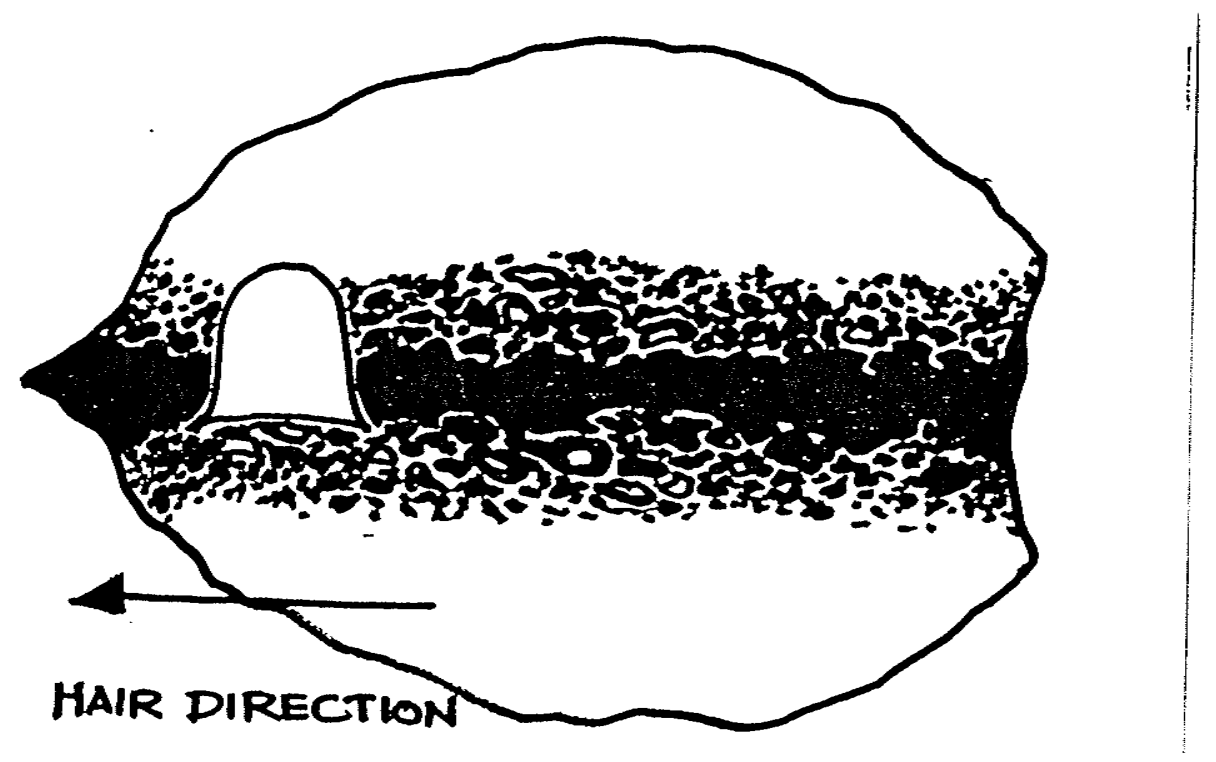

Figure 25. The Instep pattern_layout. The instep pattern is placed with the hair direction going across the instep widthwise.

\section{IV.5.2.3 ASSEMBLY}

The strip and instep are sewn together by using the steps given in subsection IV.5.1.7. The instep-strip section is then sewn to either the upper section or the sole. Stitching the instep-strip to the upper section may make sewing on the sole easier. Some sewers prefer to sew the instep-strip onto the sole before attaching it to the upper section. The 
ankle point (e) is matched to the strip-instep side seam. The instep and upper center front are marked so the fullness can be evenly pleated. Beginning at the ankle point each piece is overcasted together from right to left, moistening the seam allowance as one sews. Stitches are made about one-eighth of an inch deep and one-eighth of an inch apart. Fullness is eased in or pleated at the front.

\section{IV.5.3 SOLES}

The sole pattern is cut out of waterproof or freeze-dried sealskin. White-waterproof skins were said to be less water resistent and more pliable in winter than soles made from black-waterproof skins (Graburn 1969, Hatt 1914, Manning 1944). Arctic Bay sewers made soles from white and black-waterproof skins interchangeably. Bearded sealskins are thicker and more durable than Ringed sealskins and are preferred for hunter's kamiks. Stefansson (1945) found soles made from an old umiak (skin boat) skin cover were the toughest and most water-proof skin. Umiaks are made from Bearded sealskins. The more flexible Ringed sealskins are used for children's kamiks and by women that have difficulty sewing through the thicker skins. Beluga, walrus or old male 
Ringed sealskin were used as substitutes for Bearded sealskin (Nelson 1969, Stefansson 1945). Walrus skins were rarely available in Arctic Bay, women did not use it for soles. Beluga was not commonly used in this region either. Freeze-dried bearded sealskin is used during dry snow conditions as it becomes weak when wet. Polar bear skin occasionally is sewn onto the sole for extra insulation and improved traction. Kamiks worn in dry weather or for special occasions have soles made from freeze-dried skins.

\section{IV.5.3.1 PATTERN DEVELOPMENT}

The sole pattern measures two hand spans long and one hand span plus about one-quarter inch wide.(fig. 26) Patterns will be longer if the instep is shorter, allowing more sole to show on the top side of the foot. The sole is made narrower or wider depending on how high one wants the sole to come up the sides of the foot.

The ends of the pattern are rounded, with one end slightly narrower than the other. The narrower end can be the toe or heel depending on individual preferences. I found it easier to pleat the sole so it fits the instep when the wider, rounded end was placed at the front. (fig. 26) Toddler's kamik soles 
are made more oval shaped than the larger sizes.

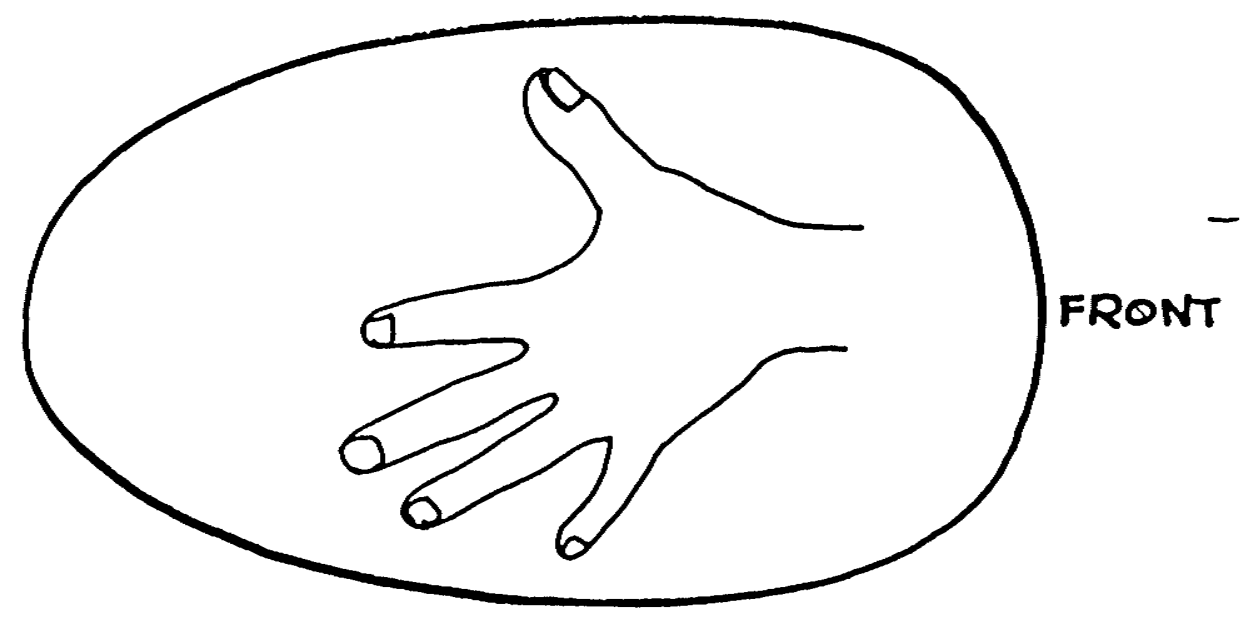

Figure 26. The sole_pattern. Soles are measured one hand span wide plus about one-half an inch.

IV.5.3.2 LAYOUT

Two sole patterns are laid out in any direction and cut one-half an inch larger than the paper pattern. This allows for shrinkage which occurs when the sole is chewed.

IV.5.3.3 SOFTENING SOLES

When one begins softening the sole it is as stiff 
as press board and has a greasy black film on the dermis. The skin is worked until it becomes cream-colored, soft and pliable. Softening is begun by wringing, twisting, folding and bending the skin with ones hands. Strong hand and arm muscles are needed to complete this step. One of the reasons women over forty gave for not sewing, was their hands were too weak to soften the skins.

The slightly pliable skin is folded into quarters and chewed enthusiastically, with firmness and lots of saliva. Women with false teeth or worn down teeth are not able to chew effectively. Some younger women dislike chewing soles because they are concerned about the condition of their teeth. One informant indicated that she asks an experienced sewer to make the soles. Other women dislike chewing the soles and do not sew kamiks.

Each sole is folded and refolded in every direction, from the dermis and epidermis side. It is chewed until it is soft and pliable. If a woman's jaw muscles grow weary the unfinished skin is placed in a freezer and is chewed at a later date. The whole skin is chewed one more time from all directions, rolled up like a 'crepe', placed in a plastic bag and kept in a cool place overnight. A day is needed to soften one sole. Manning (1944) states this was usually done by 
girls and young women.

I attempted an easier technique of softening the sole suggested to me by $S$. Naitok of Chesterfield Inlet (personal communication 1984). I sprinkled warm water over the skin and forced it through a wringer washing machine. After one and a half hours of working the skin from every direction it had the same softness as a freshly chewed sole. The 'wringer-softened' sole was examined critically by informants and found to be as good as a chewed sole. Up to this time informants said wringers were not used to soften skins in Arctic Bay. In Chesterfield Inlet, Naitok uses a wringer washing machine to soften her sealskins. Once the skin is pliable she dips it into a bowl of warm water mixed with a bit of salt and dish detergent, rubs the skin with lard or goose fat, wraps it in a plastic bag and puts it under a sofa cushion overnight. It is not certain why this is done.

\section{IV.5.3.4 ASSEMBLY}

In order to sew the sole to the instep-strip it has to be chewed one more time and thinned down. A thin slice of skin, about two inches wide is sliced from around the sole's edge. The outer two inches of the edges are chewed again. One informant rolls the 
pieces up and places them in a tall glass. She adds about two inches of water so that only the edges are soaking, preventing the center from getting wet and turning soft. She allows them to soak for about ten or fifteen minutes before sewing. Softening the sole edges enables one to make tiny, compact crimps.

A curved scraper is used to scrape the dermis side of the sole until it is soft and white. The paper pattern is placed onto the sole and excess skin is trimmed away. The center front $(y)$ and back ( $z$ ) points are marked by nicking the dermis. The instep is placed two to three inches down from the center front mark. A nick is made in the sole (w) opposite the instep-strip seam. About one-third and two-thirds of the way down from the toe nicks $(v)$ and $(x)$ are made to indicate the beginning of the toe and heel crimping. (fig. 27)

The instep-strip section is matched with the dermis showing on the instep placed against the dermis of the sole (wrong sides together). Beginning at the right hand side, the sole is brought up and laid on top of the instep. The sole overlaps about one-quarter to three-eighths of an inch, matching the instep-strip seam with the corresponding nick $(x)$ on the sole. 


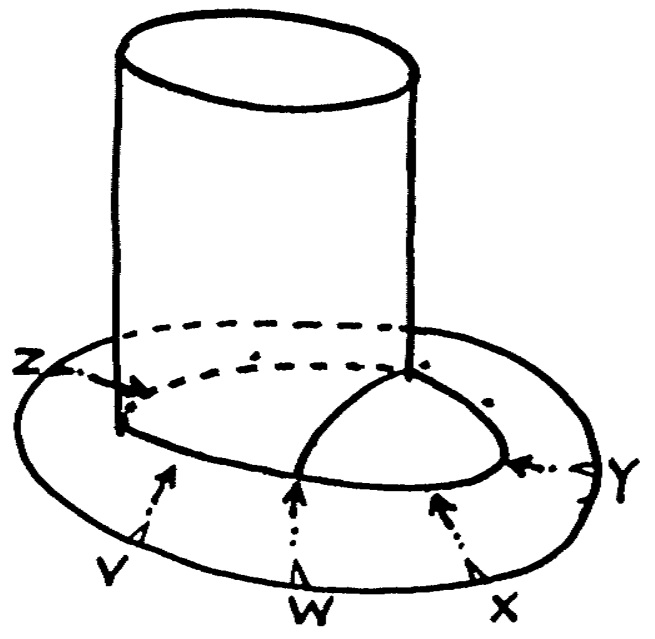

Figure 27. Matchhing_the_sole_to_the_upper_section. Nicks are placed at the center front $(y)$, beginning of the toe crimping $(x)$, beginning of the heel crimping (v) and center back (z) positions.

The first stitch is made by drawing a knotted thread through the instep from the wrong side to the right side. The needle is then pushed through from the right side of the sole into the right side of the instep. It is critical to penetrate only one-half way through the instep skin in order to prevent water from leaking through the needle holes.(fig. 28) The next stitch takes a bit more material from the sole side than from the instep side. Stitch lengths on the sole gradually increase until the center front nicks of the 
instep $(y)$ and sole match.

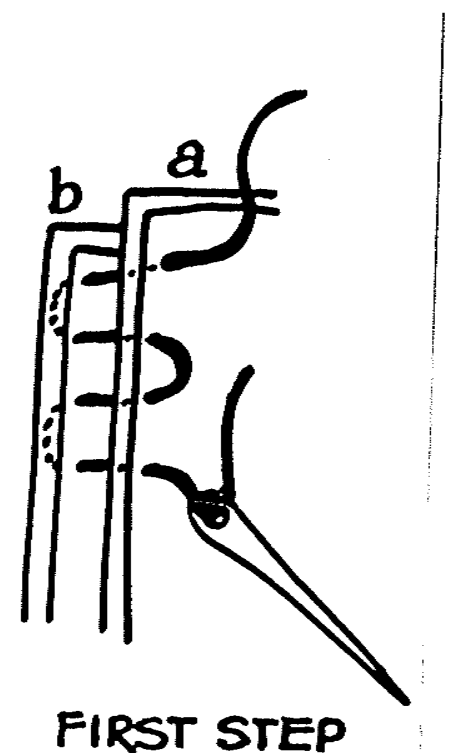

Figure 28. The first_step_of_the_waterproof_stitch. Notice the needle penetrates half way through the back piece (b).

The size of the crimps are gradually reduced when working towards the left strip-instep seam. The sole is crimped evenly because too much fullness in one spot will cause the kamik to twist. It is also important to make many tiny pleats rather than a few large pleats so the seam is tighter, allowing less moisture to seep through the folds. Small pleats are easier to make if the seam allowance is moist. Women frequently suck on the seam allowance to re-moisten the skins. The moist skins are pinched together 
forming pleats.

The left side, between $(w)$ and $(x)$, is sewn together without any crimping.(fig. 27) The heel is crimped in the same manner as the toe, carefully matching center back and side notches. The right side, betweem the beginning of the toe crimping $(x)$ and end of the heel crimping $(v)$ is completed without any pleating.

The kamik is turned inside out by poking the toe towards the heel as far as possible. The upper section is then rolled down, the toe is grabbed from inside, and firmly pulled inside out.(fig. 29)
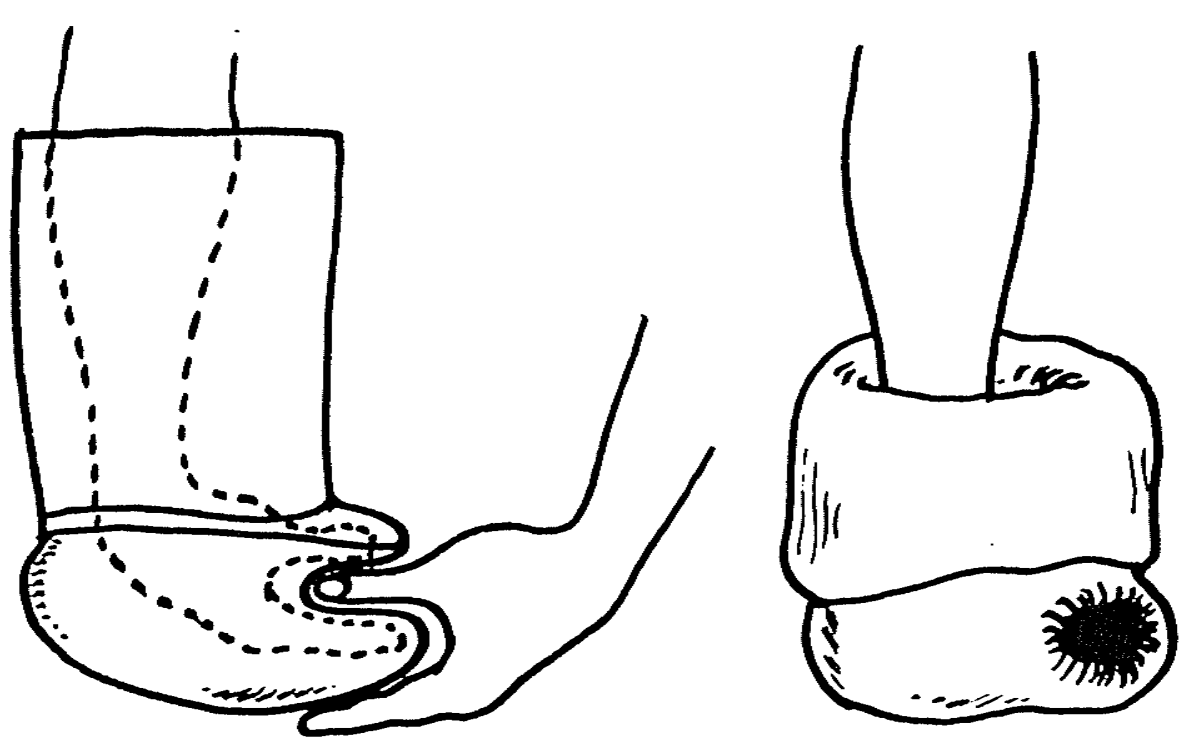

Figure 29. Turning_a_kamik_inside_out. A kamik is turned inside out by tucking in the toe, rolling down the top and pulling the toe. 
While the sole is still damp, the seam allowances are stitched to the sole using a unique overcast stitch (fig. 30). The overcast stitch is made with one-eighth inch deep stitches placed onesixteenth of an inch apart, care is taken not to penetrate through the sole skin.

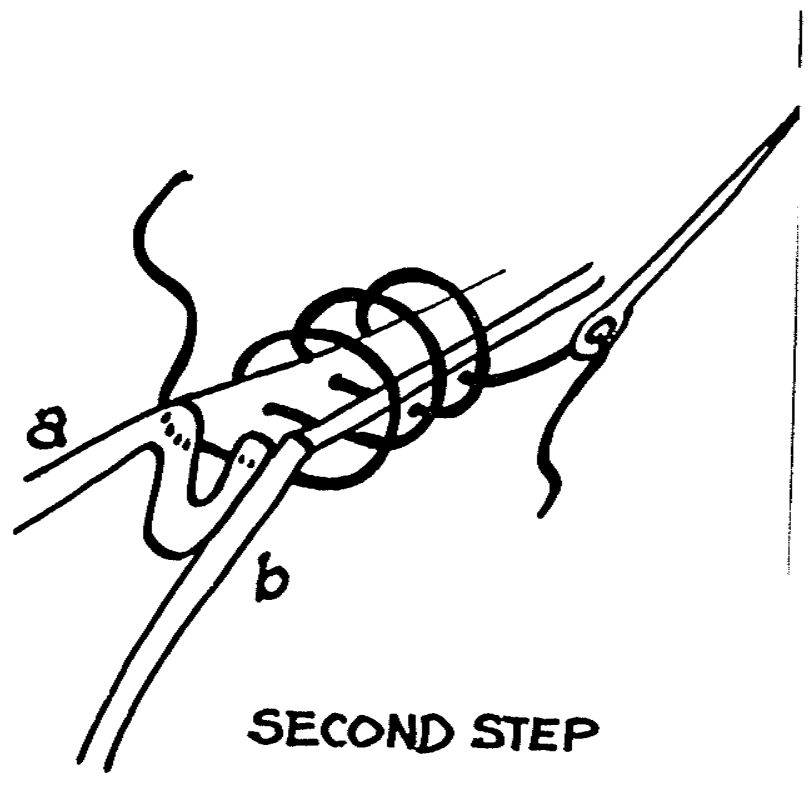

Figure 30. A water-tight_eyercast_stitch. This stitch penetrates half-way through one skin. It is $s$ used to finish the seam allowances of winter kamiks.

While the kamik is still turned inside out, running stitches are sewn through the crimping to give the kamik shape and a good fit. A triangular glovers needle and knotted thread are used to make one-eighth to one-quarter inch long stitches which pass only 
through the inside layer of the sole skin. The first row begins about three-quarters of an inch away from the bottom of the heel and just before the crimping. The second row is about one-half an inch higher, beginning and ending with the crimping. These rows continue to about one inch from the instep-strip seam. Only one or two rows are placed around the toe's crimping.

Freeman (1978), Hatt (1914), Turner (1894), Pharand (1975) and wilder (1976) describe the way women in other regions crimp soles. Utensils such as flat-nosed pliers (Nelson 1969), teeth (Turner 1894), and dull knive blades (Wilder 1976) are used to press the pleats in. Arctic Bay sewers do not use any of these tools. They chew the sole thoroughly around the edges so the damp skin easily presses into pleats.

The completed kamik is turned right side out. Teeth and hands are used to gently pull and tug at the foot until it forms a foot-like silhouette. Rows of knots may be added to the sole for more traction.

IV.6 SPRING RAMIR CONSTRUCTION

Spring kamiks are more comfortable than rubber boots because sealskin breaths, allowing body 
vapour to escape through the skin. Rubber boots do not breath, body vapours are absorbed by the socks. Feet are kept dry in deep water by tieing the kamiks tightly, so water does not spill over the tops. Male and female spring kamiks are made from cream-colored, de-haired skins or shaved skins. (fig. 31 and 32) The shaved skins are water-proof, the skins with the epidermis removed are water-resistant.

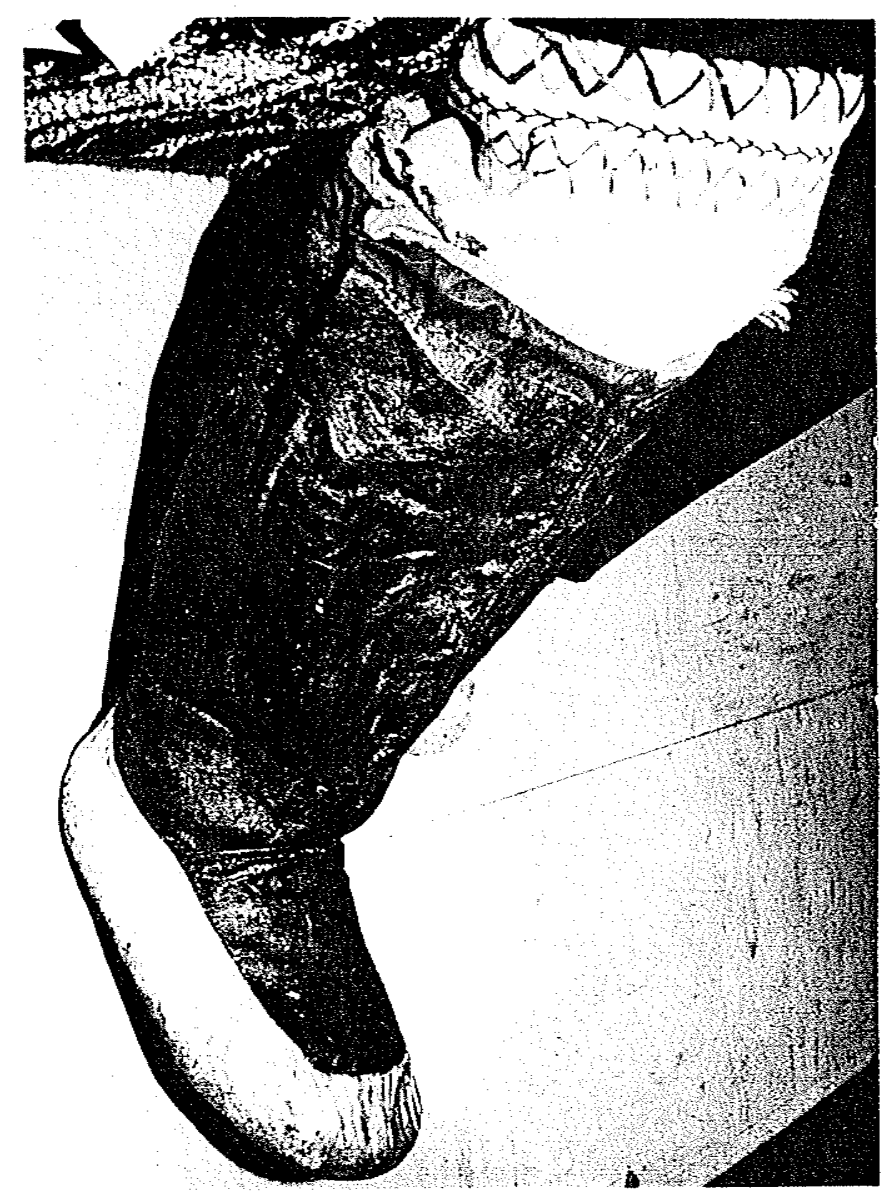

Figure 31. Water_proof_kamiks_mąde_with_shaved skins. These kamiks are worn by men and women. 


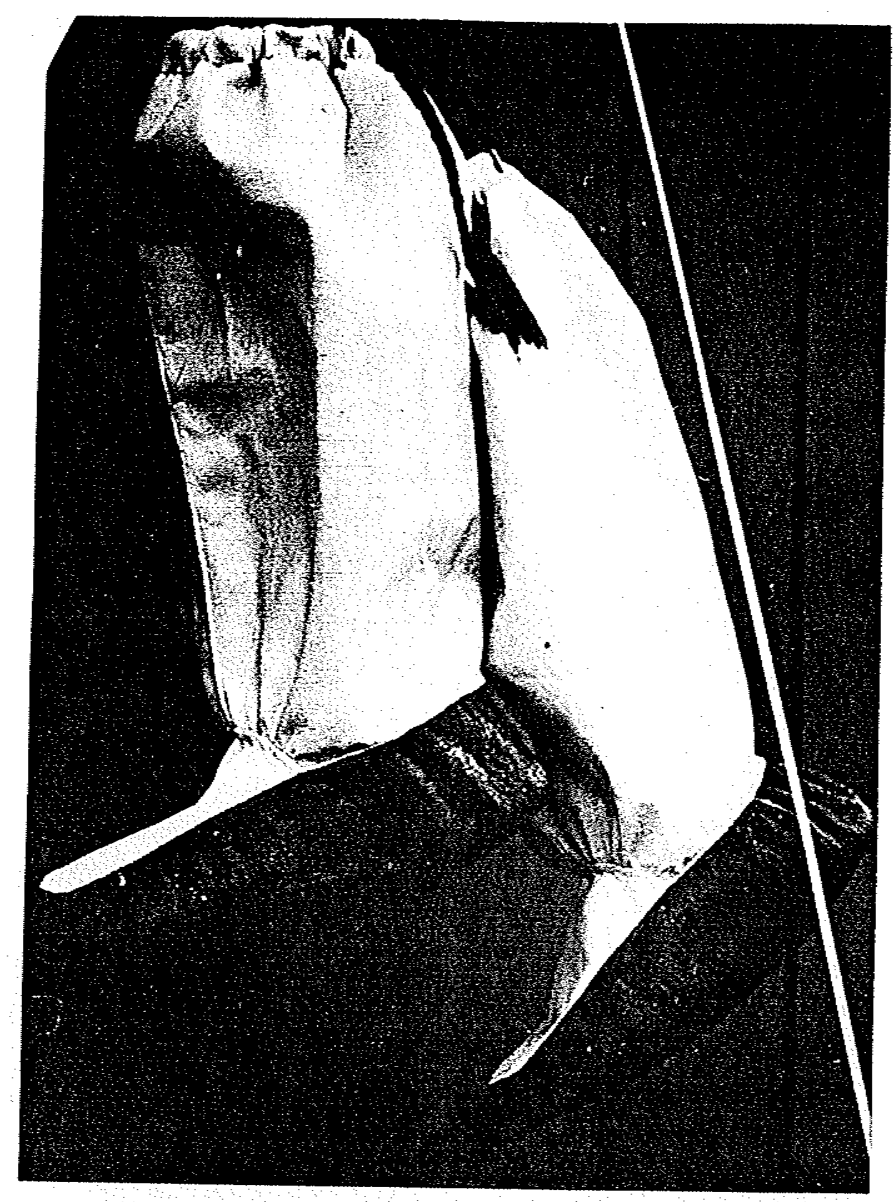

Figure 32. Kamiks_made_from_skins_with_the__hair_and epidermis_zemoyed.

Spring kamiks consist of an upper section, instep and sole. Each section is discussed seperately in the following subsection.

IV.6.1 UPPER SECTION

The upper section is cut from water-proof skin and the seams are sewn using the water-proof stitch. 
IV.6.1.1 DESIGN DEVELOPMENT

The spring kamik upper section is designed following the handspan measurement technique outlined in section IV.5.1.1. The upper edge may be decorated by sewing a two inch wide strip of dark haired skin onto it. A fabric casing is sewn to the top. Some seamstresses omit the haired skin trim, cut the upper section a few inches longer and sew the casing directly to the top edge. Others cut horizontal slits around the top and weave the tie through the slits. These methods of attaching the tie will allow some water to seep through the top. A tighter closure is made by lengthening the upper section about four inches and making a casing by folding the skin to the outside, water-proof stitching it to the kamik. Spring kamik styles have changed over the past century. Until the $1960^{\prime}$ 's men and women wore a mid-calf length spring kamik for 'around-the-home' wear. Ramiks worn for hunting purposes extended to just below the knees, this style prevails today. Graburn (1969) also describes waterproof kamiks which extended to just below the knee.

Thigh-high waterproof kamiks were used when men fished at weirs. One informant recalled helping her mother make this style of kamik when she was a young 
girl. It took two sealskins to construct one pair and the upper section's seam was either at the center back or on the in- or outside. When the seam was placed on the in- or outside of the legging it matched the instep seam.

This kamik style was used until the $1960^{\prime} \mathrm{s}$ but is not common in Arctic Bay today. Mathiassen (1928) recorded men's kamiks measuring 47 centimeters (18 $1 / 2$ inches) high at the center back and 64 centermeters (25 inches) high at center front. Two pieces of walrus hide reinforced the sole. Women's kamiks were 15 centimeters ( 6 inches) higher in the front. These kamiks were long enough to tie or button onto waistline straps or a girdle.

IV.6.1.2 SPRING RAMIK INSETS

older informants remembered sewing shaved waterproof sealskin insets into the cream-colored sealskin upper sections of women's kamiks. From the $1920^{\prime} \mathrm{s}$ to the 1930's, black bands encircled the kamik tops. By the 1930's to 1940 's kamiks were worn with a zigzag border of black skin along with simple floral and geometric designs. Very few spring kamiks were decorated by the 1960's and none were decorated in 1984 . 
IV.6.1.3 LAYOUT AND COTTING

The upper section is laid onto the skin so the lengthwise (head-tail) grain runs vertically down the pattern. The upper section is stronger when cut on the lengthwise grain because sealskins stretch more in that direction. The pattern is cut out with a sharp ulu.

IV.6.1.4 SEWING

Pieces are examined for small holes and patched using a waterproof stitch. Patches are cut about one-eighth of an inch larger than the hole to allow for seam allowances. The seam allowances and thread are moistened. One-eighth inch stitches are taken one-sixteenth of an inch from the edge of the patch. A similar stitch is taken along the edge of the hole. The stitches are pulled tight only when the needle is coming up through the main piece, not when it is coming through the patch. As the seam is sewn, the patch's seam allowance will curl under to the inside. The skin is turned to the opposite side and the procedure is repeated.

The center front seam is stitched, using the first step of the water-proof stitche illustrated in 
figure 28. The seam is kept moist and the stitches are pulled tightly every third stitch. The second step of the water-proof stitch is completed by taking a one-eighth inch long stitch, one-half of the way through the bottom piece. The needle is pushed back through the top skin and a one-eighth inch long stitch is made so it penetrates only half-way through the bottom skin. Every second stitch is pulled snug, causing the seam allowance to curl inwards. (fig. 33) Pharand (1975) describes a similar stitch used by the women in Igloolik.

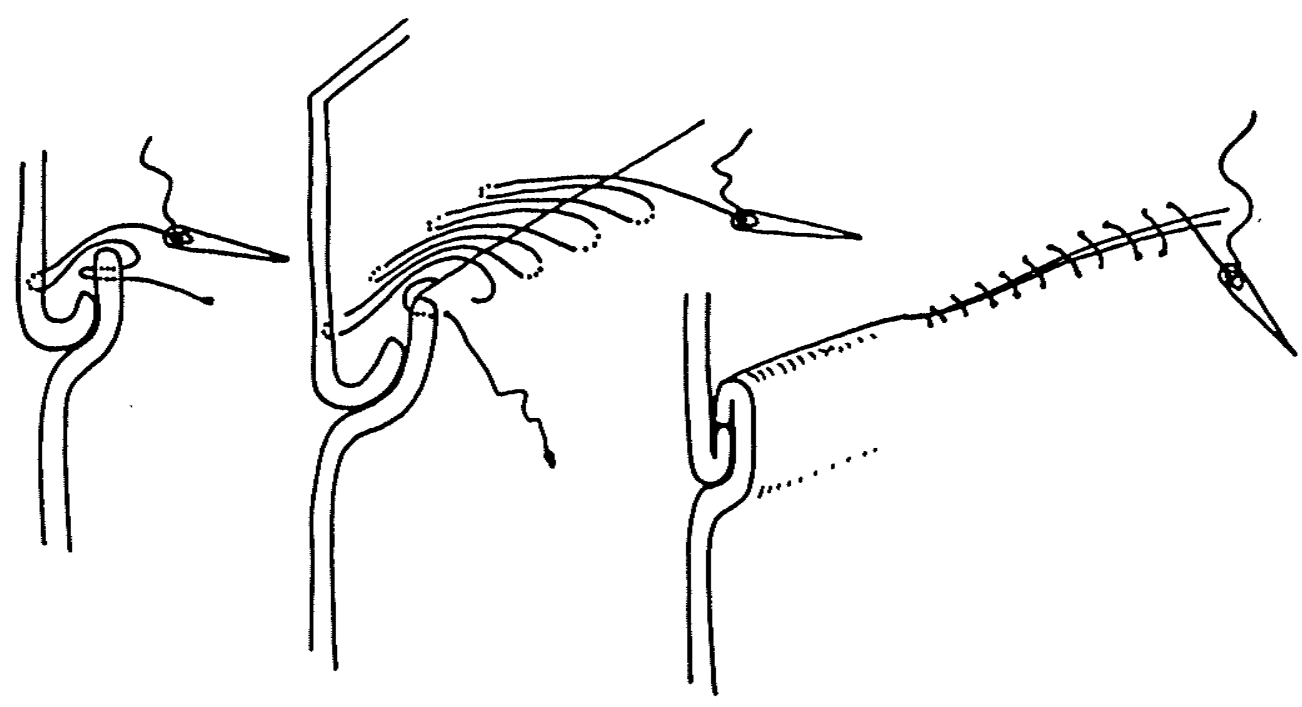

Figure 33. The secend_step of the water-preof stitch. When the stitch is pulled tight, the seam allowance curls to the inside. 


\section{IV.6.2 SPRING RAMIR INSTEP}

Pattern development, layout and cutting is completed following the directions given in section IV.5.2.

Center front notches on the instep and upper section are matched with the wrong sides together. starting at the right side, seam allowances are moistened and a one-eighth inch stitch is taken in the instep skin. The stitch penetrates partway through the skin. A slightly longer stitch is taken from the upper section, creating soft gathers at center front. Every third stitch is tightened. Once the seam is completed the inside seam allowance is sewn using the second step of the water-proof stitch. (fig. 33)

A unique instep style extends partway or all the way up the upper section.(fig. 34) This style was used by people living in camps surrounding Arctic bay from about 1935 to the 1960 's. Walrus hunters in the Igloolik area have used the extended instep before the $1920^{\prime} \mathrm{s}$, and it is still being used in that region today. One advantage the extended instep has over the common instep is it iliminates the instep seam. This prevents the possibility of the instep seam from leaking. 

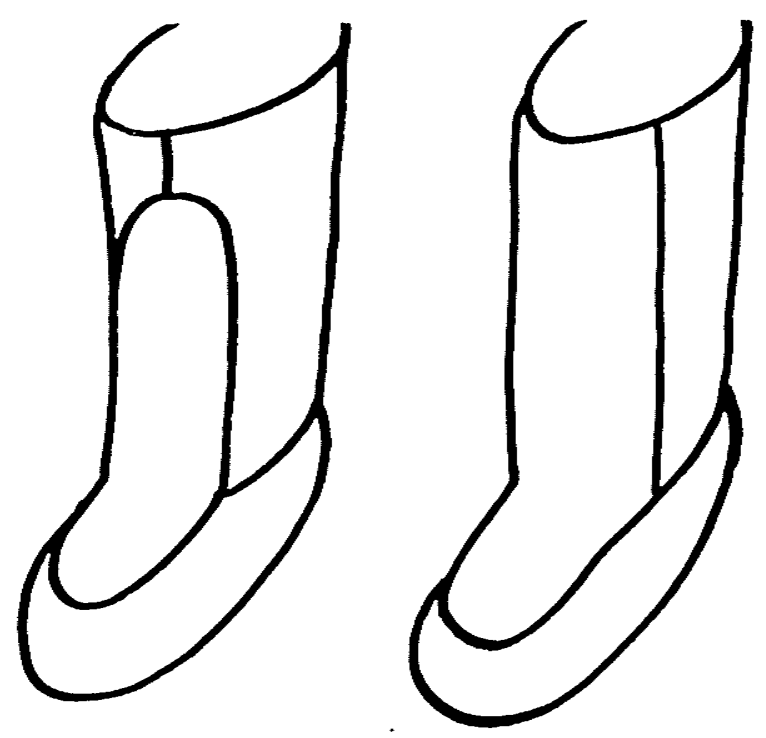

Figure 34. Water-proof_kamik_instep_styles. The extended instep iliminates the instep seam and possible leakage from the ankle area.

IV.6.3 SOLES

Sole construction is given in section IV.5.3.

IV.7. CARE and MAINTENANCE OF SPRING and WINTER RAMIKS

Spring kamiks are soaked in water for ten to thirty minutes to allow the sinew to swell, occluding needle holes. Nelson (1967) and stefansson (1945) also suggest pre-soaking kamiks before using them as 
waders.

Kamiks are mended regularly. Broken seams are repaired before the whole seam loosens and patches are sewn to thinning soles. When kamiks begin to lose their shape they are turned inside out, re-chewed and tugged at until the toe and heel regain their form. A wooden post is used to help pull the sole into shape.(fig. 35)

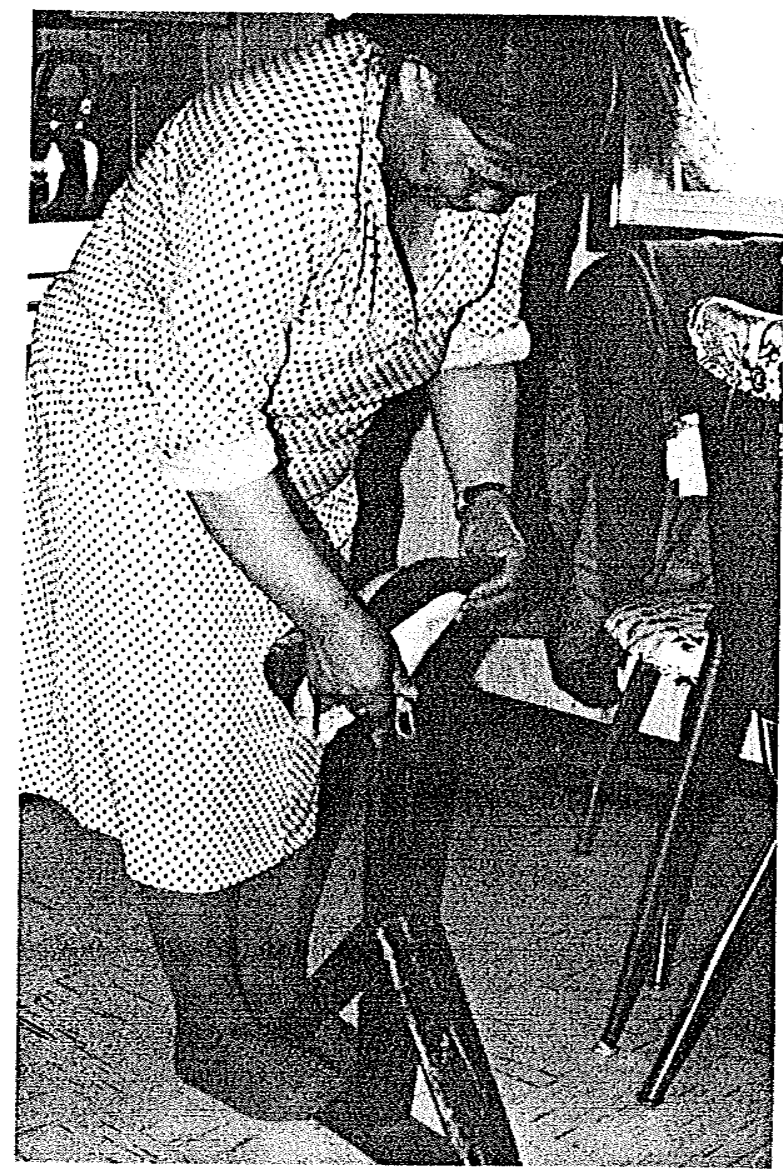

Figure 35. Kamik_stretching_post. A wooden post is used to work kamiks back into their proper shape. 
Turner (1894) said women in northern Quebec protected their kamiks from blood and fat stains by removing them while scraping skins. This was not done in Arctic Bay.

When feet are too hot they perspire, making stockings and the inside of the kamiks damp. Ramiks also become damp from condensation forming on the outer skin surface and from extended periods of wading. According to stefansson (1945), cold, salt water takes longer than fresh water to ruin a sealskin boot. Bacteria grows just on the inside of the skin where body heat has raised the water temperature high enough to breed bacteria. Fresh water is usually warmer, stimulating bacteria to develop on the inside and outside of the skin. Hence, wading in fresh water makes kamiks more susceptible to rotting. Dried polar bear, dog (Canis familiaris), and wolverine (Gulo gule) skins rot more slowly than seal or caribou. Tanned or cured skins are the fastest to decompose (Manning 1944).

Sealskin boots will stand several months of dampness if they are dried out every two to three days (Manning 1944, Stefansson 1945). In order for bacteria to be killed by desiccation, kamiks must be kept dry for a couple of days before re-using them. 
During dry weather two pairs of kamiks are needed, one pair is drying while the second pair is being worn. During wet conditions a third pair is required in order to allow the last pair used to remain dry for several days. When wearing sealskin kamiks throughout the day and while sleeping, the maximum time between dryings is reduced to less than two days (Stefansson $1945)$.

Sealskin kamiks must be dried slowly, inside out. They must not be allowed to become over-dried before being scraped or they will shrink and stiffen (Manning 1944, Stefansson 1945, Turner 1894). One method of drying kamiks is to hang them outside until they freeze and beat off the frozen ice crystals. Graburn (1969) and Nelson (1969) suggest hanging kamiks at least ten feet away from a kitchen stove to dry. My informants cautioned against using this method. Excessive heat makes skins brittle. Ramiks can also be dried by sleeping on them or by carrying them under ones parka.

Kamiks are softened, before they are completely dry, by scraping and pulling them over the tool shown in figure 33. Freeman (1978), Herbert (1976) and Manning (1944) also observed this procedure being used. After kamiks are softened they are rumpled up and worked back and forth with the hands. Teeth are 
used to pinch and pull the heel and toe into shape. When the skin boots are dry the leg is folded up like an accordian and packed into the boot sole or wrapped around the sole (Stefansson 1945). 
Chapter V. DISCUSSION AND CONCLUSIONS

\section{0 DISCUSSION}

Social, physical and economic factors influence sealskin preparation and kamik construction. These factors are discussed independently, however they are intertwined with broad, far-reaching issues such as the European fur market and political policies.

Physical environment factors:

Kamik production is directly influenced by weather, terrain, availability of sealskins, availability of work space, sewer's physical health, regional differences and centralization of communities.

The interrelationship between temperature, sunlight, wind and humidity regulates skin drying time and the drying process selected. Temperatures, precipitation and terrain influences decisions on whether to wear winter kamiks, spring kamiks or purchased footwear.

The availability, age and condition of sealskins are factors considered along with the 
kamik's size, the pattern piece and the intended use of each pair of kamiks. For example, Bearded sealskin is preferred for the soles of kamiks worn by hunters. When this is not available, Harp or Ringed sealskin is substituted, reducing the kamiks' durability. Pliable, short haired, young sealskins are preferred for children's kamiks.

Kamik production depends on the sewer's ability to sharpen an ulu, scrape and shave skins evenly, stretch and dry skins carefully, sew a waterproof seam, size up another person's foot and maintain the finished product. In order to accomplish these tasks physical space and strength is required. Suitable room to work in, adequate ventilation, cool storage facilities, easy-to-clean flooring and running hot and cold water are physical factors which influence the feasibility of kamik production. Scrap lumber, nails, saw blades, and kitchen sink cut-outs left over from construction influence the tools used in kamik production. The difficult to make and sharpen, stone and bone tools have been substituted by stainless steel and aluminum ones. These new materials have made kamik production easier.

Strong arms, good eye-hand coordination and energy is needed to prepare and sew skins. 
Seamstresses with low physical strength, failing eyesight, worn teeth and poor general health find it uncomfortable and difficult to produce kamiks. Some are able to make kamiks if they use thinner skins or nylon fabric which is easier to sew.

Poor health also influenced when women

learned to sew and the number of kamiks they produced. As a result of extended hospitalization in tuberculosis rehabilitation centers wome women learned to sew kamiks five years later than their peers. Other women were unable to sew, even though they knew how, for one to two years while they were hospitalized in southern rehabilitation centers.

Women's age also appeares to contribute to whether or not she sews. Women between thirty-five and sixty are active kamik producers today. Very few younger women produce kamiks. Women born before the 1950's generally began producing kamiks for family members by age twelve to fourteen. Women born in the 1960 's or $1970^{\prime}$ s rarely sew kamiks today. Some younger women expressed concern about wear on their teeth and disliked the black flecks of epidermis which collect on the teeth when chewing soles.

Regional differences affect kamik styles. A mixture of social and physical environments create unique regional environments. Women from different 
regions make kamiks with different styling. The extra gathers in the upper section and the intricate inlaid designs are characteristics found in Arctic Bay. These differences are intimately related with personal preferences and social factors.

Social Environment Factors:

The seamstress's personality, family, role, education, exposure to southerners, religious beliefs and community involvement influence kamik production. Ramik construction is learned from relatives yet each sewer constructs kamiks with a personalized flare. Community members could match kamiks to the appropriate sewer by looking at the style and decoration. Each sewer creates her own style of kamik by combining characteristics she likes in several other people's kamiks, adding her own creative ideas to produce a unique piece of artwork.

Women's roles, men's roles and family composition influence the number and type of kamiks needed. Traditionally, the female role included the never ending task of constructing kamiks for their entire family. The influx of police officers, teachers, missionaries, explorers and scientists created new requests for kamiks. Ramiks were usually 
made looser for those people who were not accustomed to wearing skin boots (Schweger 1983). As more services were offered in Arctic Bay, families gravitated towards town. Women reduced the amount of time spent with their families hunting and some acquired jobs in town. Mass-produced footwear is more practical for wearing in the community. Young children and family members who hunted still needed kamiks as they are warmer than pruchased footwear. When Pan Arctic Oil Drilling and Nanisivick Mining operations began in the Arctic Bay area, Inuit men's roles began to shift from hunting to working at local jobs. Steel-toed boots, rubber boots, running shoes, and skidoo boots met their footwear requirements. Grease, mud, chemicals and the danger of dropping heavy equipment reduced the practical and safety aspects of kamiks.

Conflicts between the Nanisivick mining operation and Arctic Bay hunters have affected seal and narwhal hunting as well as men's roles and footwear requirements. The Nanisivick mine ships lead and zinc in early June, six to eight weeks before the ice normally breaks up. Early shipping speeds up the annual ice break-up, disrupting floe-edge hunting of narwhals and seals (Dahl 1984, oral and written communication). Shortened ice hunting seasons reduce 
the need for kamiks to protect hunters feet and reduce the number and variety of skins returned to sewers. Changing role models may have contributed to the shift away from traditional skills. Women who grew up in the outposts emulated their elders. Arctic Bay residents were exposed to southern role models such as nurses and teachers who were often unfamiliar with traditional Inuit lifestyles. A lack of encouragement or respect for the skills needed to make kamiks may have deterred some young sewers who were attempting to emulate the southern lifestyle of their role models.

Family size and life cycle contributed to the many factors influencing kamik production. Women with large families make about two pair of kamiks per month while women with smaller families make one or two pair a year. Women who's children have moved away from home, sew fewer kamiks than when their children were living at home.

New education values have influenced how kamik construction is taught and the value placed on the end product. Informants who were educated in southern centers such as Frobisher Bay, Churchili, Winnipeg, Montreal or Ottawa, found that they did not learn to construct kamiks until they returned to Arctic Bay and became re-established in the community 
lifestyle. Southern environments do not provide the teachers or materials needed for a woman to learn how to make kamiks. Women who had been educated outside Arctic Bay mentioned that there was not enough time to learn sewing skills nor were there people who knew how to teach them.

During the summer holidays students return to Arctic Bay. However, kamiks are seldom sewn during the summer so students rarely are taught the techniques.

The method of teaching kamik construction has changed. Traditionally, girls were taught to sew by their mothers or grandmothers. Elders waited until they felt the girl was ready to learn. Steps were demonstrated and handed to the student to try. When the student ran into difficulty the teacher would work over the difficult portion and pass it back to the. student. Consequently, the first kamik was made well enough to be worn. Today, girls are taught in course called 'Culture' at school. The procedure is demonstrated and each step is completed by the student. The first pair of kamiks often contain many errors and are generally thrown into the garbage. Rarely does the student attempt a second pair. In an attempt to teach young women how to sew kamiks one informant began evening courses in kamik 
construction. This was a success in that the women made one or two pairs of kamiks for their family that year. Towards December community dances and social events were reasons given for the classes to disband. The introduction of contemporary religious beliefs influence when kamiks are sewn. Anglican and Roman Catholic missions stress the importance of not working on Sundays. AII sewing and skin preparation comes to a stand still on this day of rest. Christmas and Easter celebrations were introduced to Arctic Bay and have influenced skin boot production as new kamiks are made for these occasions.

Social events at other times of the year have placed kamik production into a new, competitive perspective. July First and the Frobisher Bay "Tunit Time" celebrations include kamik competitions. Women from all over Baffin Island enter their finest kamiks in the craft shows.

Economic Factors:

New jobs, changing fur prices and conflicts with foreign industry have influenced kamik production. In 1939 the Inuit from Baffin Island and Nouveau Quebec sold kamiks to local Budson Bay posts for $\$ 1.25$ to $\$ 1.50$ per boot. These boots were packed 
one thousand to a crate, with a bottle of seal oil in each kamik. Winnipeg's Hudson Bay office received the shipments and redistributed them to northern Manitoba settlements such as Norway House, York Factory and Nelson House. Northern posts bought the boots for $\$ 1.75$ and sold them to trappers for $\$ 2.35$. When world War II began, supply ships were sent over seas and the Hudson Bay Company in Winnipeg stopped recieving kamiks from Inuit women. After World War II was over, kamik shipments did not return to the pre-war volume of production. Changes in lifestyles, government support programs and a demand for soap stone carvings may have deterred women from selling kamiks to the Hudson Bay Company (Cotter 1985 personal communication).

In 1955 Ringed sealskins sold for $\$ 1.50$. Prices rose to $\$ 12.25$ by 1963 , enabling Inuit to purchase better rifles and vehicles. This price increase was partly a result of improved tanning processes in the south which popularized sealskin's use in the garment industry. At the same time women began using nylon fabric for the upper section, allowing more sealskins to be sold. Negative publicity on sealing in 1967 corresponded with a 508 drop in sealskin garment sales. Aggressive anti-sealing campaigns in 1976-77 caused the price of a sealskin to drop to $\$ 1.00$ (Herscovici 1985). Today, 
the market for sealskins is nonexistent. However, kamik designs have become more intricate and complicated. More time and materials are used to create exquisitely hand crafted kamiks. The drop in the sealskin market in 1964 corresponds with many women returning to using skins in kamik uppers rather than nylon fabric.

\section{V.I CONCLUSIONS}

Presently, in Arctic Bay, sealskin boots are made primarily by women aged thirty-five to fifty-five years old. Social, physical and economic factors such as family size, lifestyle, health, knowledge and abilities of the sewer; the availability, price and condition of seal pelts; and the end use of skin boots influence skin boot production. Factors interrelate. with each other, making it difficult to complete a cause and effect analysis.

From a broader perspective kamik production is affected by government policies, economic changes and technology.

Inuit experienced very little contact with Euro-Americans from 1822 until 1945. The introduction of family allowance, government pension and unemployment benefits helped to instigate a dependancy 
on imported goods. New technology such as rifles, boats, motors, and snowmobiles depend upon a cash economy for maintenance.

In the early $1960^{\prime}$ 's the Canadian government encouraged Inuit families to move from outposts into centralized, subsidized housing. Women ten years or older at the time of this major change in lifestyles, remain active kamik sewers today. Younger females have grown up with little interest in learning kamik production skills. Centralized community life increased the medical, religious, legal and educational services available to the Inuit. The subsequent change in lifestyles has influenced kamik production.

The combination of technology and a cash economy created a state of disequilibrium, rapid adaptation to new lifestyles was necessary in order to survive. Some of these adaptations can be seen in changes in skin boot production. For 5000 years Inuit were able to produce footwear that protected them from the elements. In the last 25 years one has seen many changes in physical, social and economic Arctic environments. Skin preparation and kamik production methods have adapted alongside these environmental changes. 
V.2 FUTURE RESEARCH

Additional research in the field of traditional Inuit clothing is urgently needed because the Inuit lifestyle and clothing needs are rapidly changing. Skills used to prepare skins, develop patterns and construct all types of skin clothing must be documented before they are forgotten. Regional differences in skin preparation, pattern development and garment construction need to be identified. A study of the social history of each garment worn by traditional Inuit would be a valuable contribution to historical costume research.

A Less urgent study would include an analysis of present day clothing styles, production methods, sources of materials and end uses of clothimg made by Inuit seamstresses. 


\section{LITERATORE CITED}

Auliciems, A., "Winter Clothing Requirements for Canada". De Freitas, C., Environment Canada Atmospheric Enyironment, \& Hare, F. 1973 Climatological_studies_No_22. Toronto UDC: $551.524 .32: 646(71)$.

Bandi

1969

Eskimo_Prehistory. Translated by A. Reep. First published in 1964, Urgeschicte der Eskimo. University of Alaska Press, Whitehorse.

Brody, H. "Inummaruit: The Real Eskimos". Inuit 1976 Land Use and occupancy Project. Vol II. Milton Freeman Research Ltd., Department of Indian \& Northern Affairs, Ottawa,pp 223-226.

Bruemmer, F. Seasons of the Eskimo. New York Graphic 1971 Society Limited. Greenwich, Conneticut.

Conn, R. A_classsification of Aboriginal North American 1955 Clothing. M.A. Thesis, University of Washington.

Dahl, J. unpublished

"Mining_and_Local_Communitiese_A_Short paper comparison_of Mining in the_Eastern_Canadian 1984 Arctic_(Nanisiyick $/$ AEctic_Bay) and_Greenland (Marmorilik/Uummannag)". Institute of Eskimology, University of Copenhagen, Copenhagen.

Driscoll, B. The_Inuit_Parka:_A_Preliminary_study. 1981 M.A. Thesis. Carleton University, Ottawa.

Environment Canada. Canadian_Climate Normalse 1951-1980, 1982

Temperature_and_Precipitation _The_North: Yukon and Northwest Territorries. UDC:551.582(712). Canadian Climate Program, Ottawa.

Fitzhugh, W. "Indian \& Eskimo/Inuit Settlement History in 1977 Labrador: An Archaeological View". Qur Foot Rrints are Everywhere. edited by $c$. Brice-Bennett. Labrador Inuit Association, Nain, Labrador. pp 1-40. 
Flugel, J. The Psychology of Clothes. AMS Press, New 1950 York.

Freeman, Milton. "Adaptive Innovations Among Recent Eskimo 1969 Immigrants to the Eastern Canadian Arctic". The_Polar_Record. $14(23): 769-781$.

Freeman, Minnie. Life_Among the Qallunaat. Hurtig 1978 Publishers, Edmonton, Alberta.

Graburn, N. Eskimos_Without Igleos. Little, Brown \& Co., 1969 Boston.

Hatt, G. "Arctic Skin Clothing in Eurasia and America, 1914 an Ethnographic Study". Arctic_Anthropology. $V(2): 3-132$. translated and reprinted in 1969 .

1916

"Moccasins and Their Relation to Arctic Footwear". Memoirs of the American Anthropological_Association. III (3) :147-250.

Hawkes, E. The Labrador Eskimo. Geological Survey 1916 Memoir No 91, Anthropological series No 14, Government Printing Bureau, Ottawa.

Herbert, G. Eskimos. Franklin Watts Inc. 1976

Herscovici, A. Second Nature, The Animal_Rights 1985 Controyersy. CBC Enterprises, Toronto.

Honogmann, J. "Social Networks in Great whale River". 1962 National_Museum_of_Canada__Bulletin_No_178. Department of Northern Affairs and Natural Resources, Queens Printer, Ottawa.

Manning, T. E. "The Preparation of Skins and Clothing in 1944 the Eastern Canadian Arctic". The Polar Record. $4(28): 156-169$.

Mathiassen, T. "Material Culture of the Iglulik Eskimos". 1928 Report_of_the_Eifth_Thule_Expedition__1221 1924. VI(1). Copenhagen.

McGhee, R. An Individual View of Canadian Eskimo 1976 Prehistory". Inuit Land_Use_and_occupancy Project. Vol II:109-115, Milton Freeman Research Ltd., Department of Indian and Northern Affairs. 
Nelson, R. Bunters of the Northern_Ise. University of 1969 Chicago Press, Chicago.

Pharand, S. "Le Vetement des Inuit Iglulik". Masters in 1975 Social Science Thesis, Laval oniversity, Montreal.

Riewe, R。 1975

"A Lesson on winter Survival from the Inuit". Manitoba_Natucure. Winter:22-33.

Riewe, R. and C. Amsden. "Harvesting and utilization of 1979 pinnipeds by Inuit Hunters in Canada's Eastern High Arctic". In Thule_Eskime Culture: an archaeological retrospective. A.T. McCartney (ed). National Museum of Man, Mercury Series, Arcaeological Survey No $88.197: 324-348$.

Ross, W. "Inuit \& the Land in the Nineteenth Century". 1976 Inuit Land Use \& eccupancy Project. Vol 11:123-129. MiIton Freeman Research Ltd., Department of Indian \& Northern Affairs, ottawa.

Schweger, B. Documentation____Analysis_of_the_Clothing_Worn 1983

By_Non-Natize_Men in the_Canadian_Arctic Prior to 1920 , with an Emphasis on Eootwear. Masters in Science Thesis, University of Edmonton.

Stefansson, V. Arctic Manual. The MacMillan Co., New 1945 York.

1955

"Clothes Make the Eskimo". Natural_History. January:32-51.

Sproles, G. Eashion: Consumer Behayior Towards Dress. 1979 Burgess Publishing Company, Minneapolis Minnesota.

Taylor, W. "The Prehistory of the Quebec-Labrador 1964 Penninsula". In Le Nouveau-Quebec. edited by J. Malaurie \& J. Rousseau. Mouton \& Co., Paris. pp 181-210.

"Fragments of Eskimo Prehistory". Inuit_Land Use_\&_eccupancy_project. Vol II:105-108. Milton Freeman Research Ltd., Department of Indian \& Northern Affairs, Ottawa. 


\begin{abstract}
Turner, L. Indians and Eskimos in the ouebec-Labrador 1894 Penninsula. Originally published as part of the lith report of the Bureau of Ethnology, Re-published in 1979, Presses Comeditex.

Wenzel, G. "The Ecology of Inuit Hunting at Clyde River, 1975 N.W.T.". Report to the Canadian_Ethnolegy Service, Ottawa.

Wilder, E. Secrets_of_Eskimo_skin_clothing. Alaska 1976 Northwest Publishing Company, Alaska.

PRIMARY RESOURCE PERSONNEL
\end{abstract}

Alainga, N. Businesswoman and seamstress, Arctic Bay, 1984 personal communications.

Alooloo, E. Resident seamstress, Arctic Bay, personal 1984 communications.

Alooloo, M. School teacher and resident, Arctic Bay, 1984-85 personal and written communications,

Attagutsiaq, Q. Seamstress, Arctic Bay, personal 1984 communications.

Barnabas, S. Seamstress, Arctic Bay, personal 1984 communications.

Campbell, R. Government interpreter, Arctic Bay, 1984 personal communications.

Cotter, G. Ex-Hudson's Bay Company employee, personal 1985 communications.

Freeman, Minnie. Writer and producer, ex-resident of 1984 Nouveau Quebec, personal communications in Montreal.

Hall, J. Collections Researcher, Canadian Ethnology 1984 Service, Museum of Man, Ottawa, written communications.

Ipilee, A. Seamstress, Arctic Bay, personal 1984 communications. 
Ipirqituq, S. Seamstress, Arctic Bay, personal 1984 communications.

Issuqangittug, R. Seamstress, Arctic Bay, personal 1984 communications.

Kigutah, M. Seamstress, Arctic Bay, personal 1984 communications.

Kalluk, L. Seamstress, Arctic Bay, personal 1984 communications.

MacDonald, J. Head of Culture and Linguistics, Department 1984 of Indian and Northern Affairs, Ottawa, personal and written communications.

Muckpa, R. Sewing instructor, Arctic Bay, personal 1984 communications.

Muckpaloo, K. Seamstress, Arctic Bay, personal 1984 communications.

Naitok, S. Sewing instructor, Chesterfield Inlet, 1984 personal communications.

Pearce, M. Nurses aid, hotel manager, seamstress, Arctic 1984 Bay, personal communications.

Riewe, R. Department of zoology, University of 1984-85 Manitoba, personal communications.

Shappa, A. Radio announcer, seamstress, Arctic Bay, 1984 personal communications.

Tungarluk, T. Seamstress, Arctic Bay, personal 1984 communications.

Willie, M. Seamstress, Arctic Bay, personal and 1984 written communications. 